\title{
Adoption levels of integrated pest management among corn producers in West Virginia
}

\author{
Hari K. Vommi \\ West Virginia University
}

Follow this and additional works at: https://researchrepository.wvu.edu/etd

\section{Recommended Citation}

Vommi, Hari K., "Adoption levels of integrated pest management among corn producers in West Virginia" (2009). Graduate Theses, Dissertations, and Problem Reports. 2809.

https://researchrepository.wvu.edu/etd/2809

This Thesis is protected by copyright and/or related rights. It has been brought to you by the The Research Repository @ WVU with permission from the rights-holder(s). You are free to use this Thesis in any way that is permitted by the copyright and related rights legislation that applies to your use. For other uses you must obtain permission from the rights-holder(s) directly, unless additional rights are indicated by a Creative Commons license in the record and/ or on the work itself. This Thesis has been accepted for inclusion in WVU Graduate Theses, Dissertations, and Problem Reports collection by an authorized administrator of The Research Repository @ WVU. For more information, please contact researchrepository@mail.wvu.edu. 


\title{
Adoption Levels of Integrated Pest Management Among Corn Producers in West Virginia
}

\section{Hari K. Vommi}

\author{
Thesis submitted to the \\ Davis College of Agriculture, Forestry, and Consumer Sciences \\ at West Virginia University \\ in partial fulfillment of the requirements \\ for the degree of
}

\section{Master of Science}

in

Agricultural and Extension Education

\author{
Stacy A. Gartin, Ph.D., Chair \\ Harry N. Boone, Jr., Ph.D. \\ Deborah A. Boone, Ph.D. \\ Rakesh S. Chandran, Ph.D. \\ Division of Resource Management \\ Morgantown, West Virginia \\ 2009
}

Keywords: agriculture, pesticides, environment pollution, integrated pest management 


\section{ABSTRACT \\ Adoption Levels of Integrated Pest Management Among \\ Corn Producers in West Virginia}

\section{Hari K. Vommi}

Modernization of agriculture has exponentially increased the use of pesticides in the last six decades. Pesticides were considered to be the only solution to control weeds, insect pests and diseases to enhance and sustain productivity in agriculture. This led to indiscriminate use of pesticides causing severe pollution to air, water, food and fiber. Integrated pest management (IPM) is the use of combinations of several alternative pest control measures to keep the pests under the economic threshold level. The United States Department of Agriculture has promoted the use of integrated pest management for the past three decades with a goal to expand the adoption of IPM to 75\% of the United States crop acreage by the year 2000.

This study was designed to determine the knowledge of West Virginia corn producers about integrated pest management concepts, their level of adoption and the educational needs on integrated pest management. The data for the study were collected via 100 questionnaires mailed to farmers in the top five corn producing counties in West Virginia. Of these, 64 surveys were returned.

It was found that $62(96.9 \%)$ of the respondent corn producers were practicing IPM concepts to some degree. Further it was revealed that more than $75 \%$ of the responding corn producers needed more information on various aspects of corn crop management. 


\section{DEDICATION}

This thesis is dedicated to my lovely wife Sunny and my wonderful daughter Cherry. 


\section{ACKNOWLEDGEMENTS}

Foremost, I would like to express my sincere gratitude to my advisor Dr. Stacy A. Gartin for his continuous support of my graduate study and research. His guidance helped me in all the time of research and writing of this thesis.

Besides my advisor, I would like to thank the rest of my thesis committee: Dr. Harry N. Boone Jr., Dr. Deborah A. Boone and Dr. Rakesh S. Chandran for their encouragement and insightful comments.

I thank all the faculty members in Agricultural and Extension Education at West Virginia University for a well-rounded graduate experience. Special thanks to Dr. Harry N. Boone for his assistance in data analysis and thesis writing. I thank Mrs. Alice Compton for her help in my research work.

I would like to thank all my friends who have taken an active role in seeing that I accomplish my goals. I would like to thank my classmates for their love and support.

Lastly, I would like to thank my family: my mother and father, Venkata Ratnam and Satya Rao, my wife Sunitha and my daughter Charishma for their support and unconditional love. I thank all my siblings for their unconditional love and affection. I would like to thank my in-laws for supporting me spiritually. Special thanks to my father who encouraged me to continue my education and to inspire me to reach my goals. 


\section{TABLE OF CONTENTS}

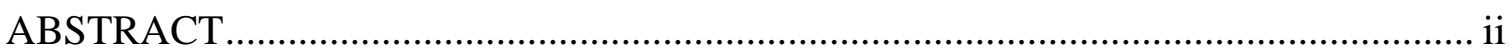

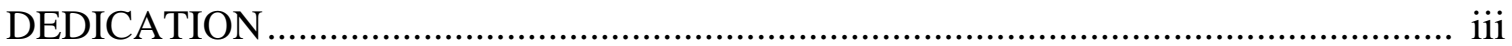

ACKNOWLEDGEMENTS .................................................................................... iv

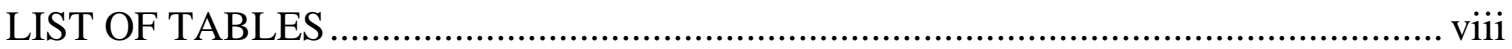

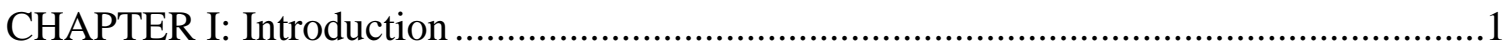

Statement of the Problem ......................................................................................

Purpose of the Study ..........................................................................................

Objectives of the Study …………….................................................................

Limitations of the Study ........................................................................................

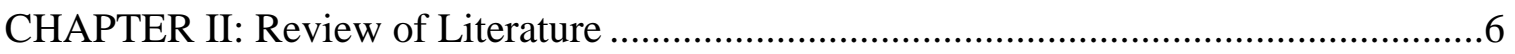

CHAPTER III: Methodology .....................................................................................12

Purpose of Study .........................................................................................12

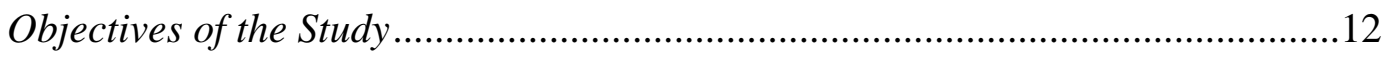

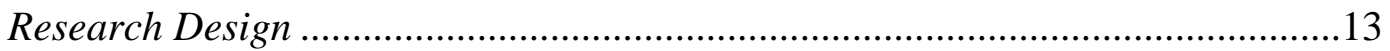

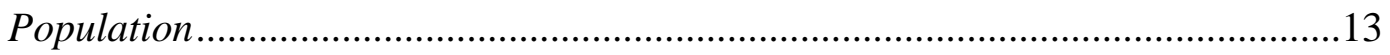

Sample

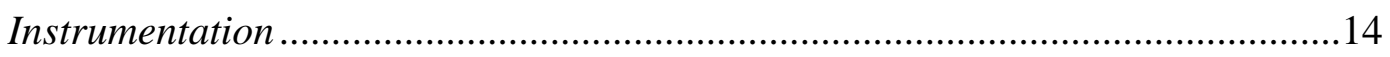

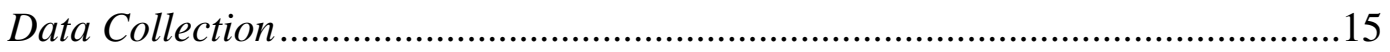

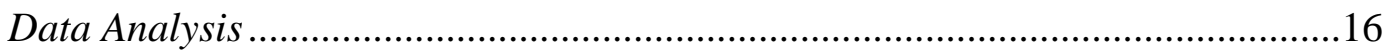

Use of Findings ................................................................................................17

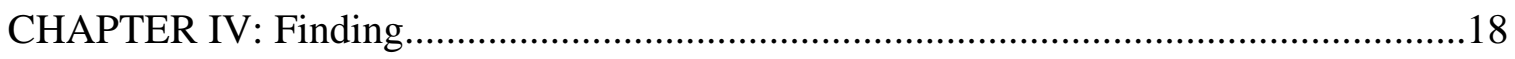

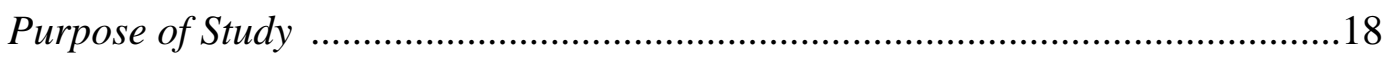

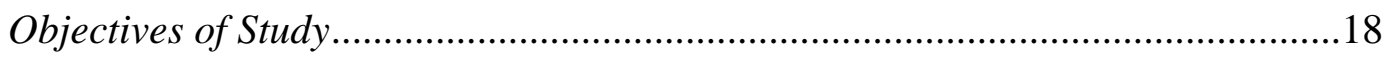

Counties Represented by Corn Producers to IPM Survey ......................................19

Gender of WV Corn Producers.......................................................................20 
Age of WV Corn Producers.................................................................................20

Acreage of Corn Grown in 2008 by IPM Survey Respondents..............................21

Highest Level of Education for WV Corn Producers..............................................21

Agricultural Classes in High School and IPM Training(s) Attended by WV Corn Producers.................................................................................22

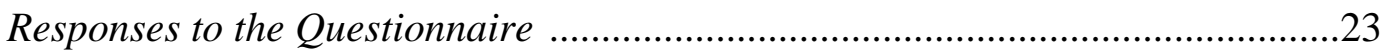

General Perception of WV Corn Producers on Pesticide Usage ...........................24

Weed Management Techniques used by WV Corn Producers.................................29

Disease Management Techniques used by WV Corn Producers .............................32

Pest Management Practices used by WV Corn Producers ......................................35

Scouting for Insects by WV Corn Producers .........................................................35

Techniques used by WV Corn Producers to Control Cutworms.............................37

Techniques used by WV Corn Producers to Control European Corn Borer.........40

Techniques used by WV Corn Producers to Control Armyworms..........................43

Techniques used by WV Corn Producers to Control Wireworms...........................45

Techniques used by WV Corn Producers to Control White Grubs.........................47

IPM Check List Responses by WV Corn Producers ..............................................50

Level of IPM Adoption by WV Corn Producers.......................................................52

Educational Needs of West Virginia Corn Producers ............................................53

CHAPTER V: Summary, Conclusions and Recommendation ...........................................55

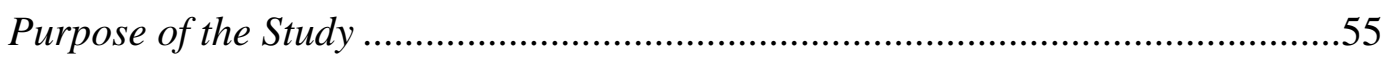

Objectives of the Study ....................................................................................5

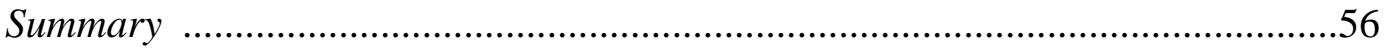

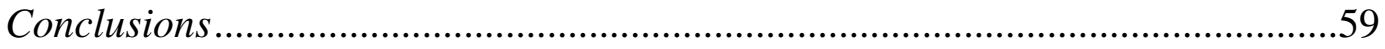

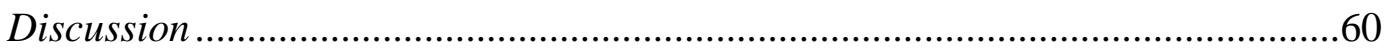

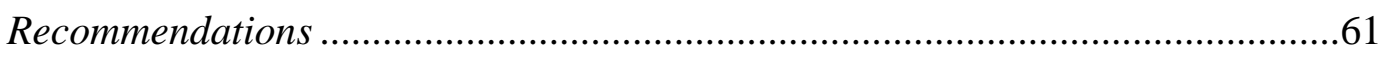

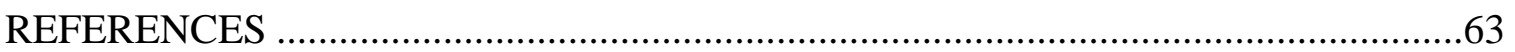

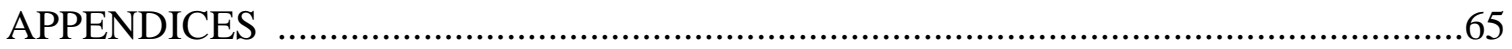


APPENDIX A: Email correspondence with the County Extension Agents

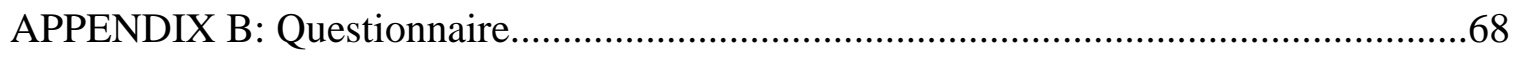

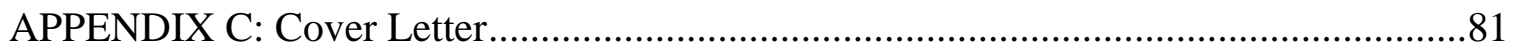

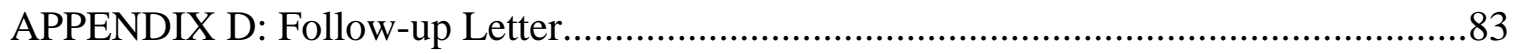

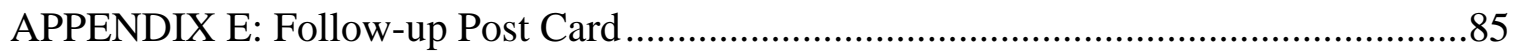

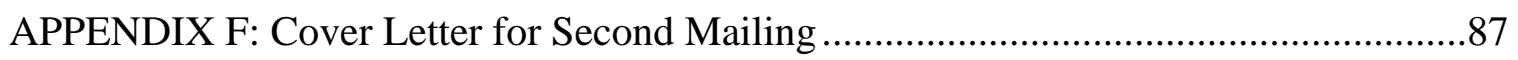

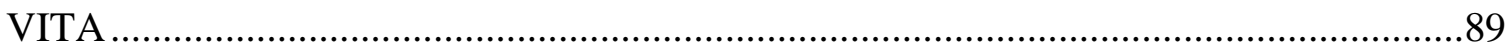




\section{LIST OF TABLES}

Table Title page

$1 \quad$ Counties Represented by Corn Producers to IPM Survey ...................................19

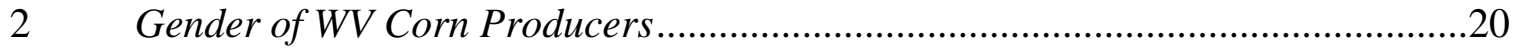

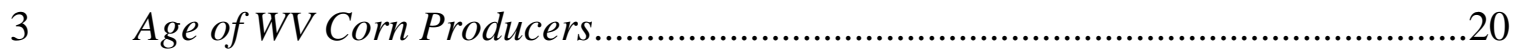

$4 \quad$ Acreage of Corn Grown in 2008 by IPM Survey Respondents............................21

$5 \quad$ Highest Level of Education for WV Corn Producers...........................................22

6 Agricultural Classes in High School and IPM Training(s) Attended by WV Corn Producers..........................................................................................2.

$7 \quad$ General Perception of WV Corn Producers on Pesticide Usage ..........................26

$8 \quad$ Weed Management by WV Corn Producers .....................................................30

$9 \quad$ Disease Management by WV Corn Producers...................................................33

$10 \quad$ Scouting for Insects by WV Corn Producers ...................................................36

11 Techniques used by WV Corn Producers to Control Cutworms............................38

12 Techniques used by WV Corn Producers to Control European Corn Borer.........41

13 Techniques used by WV Corn Producers to Control Armyworms.........................44

14 Techniques used by WV Corn Producers to Control Wireworms..........................46

15 Techniques used by WV Corn Producers to Control White Grubs.........................48

$16 \quad$ IPM Check List Responses by WV Corn Producers ...........................................51

17 Level of IPM Adoption by WV Corn Producers.................................................52

18 Educational Needs of WV Corn Producers .........................................................54 


\section{CHAPTER I}

Introduction

Modern agriculture is very challenging and requires many inputs like fertilizers, pesticides and farm implements. Pesticides are a crucial input that plays a major role in sustaining the productivity of food and fiber. The United States Environmental Protection Agency (EPA) (2008) reported that there are over 20,000 pesticide products containing 620 active ingredients available on the market. Every year one billion pounds of conventional pesticides are used in the United States. There are about 80,000 existing chemicals noted in the Toxic Substances Control Act (TSCA) and another 2,000 chemicals are being added (EPA, 2008).

Though pesticides are critical inputs in agriculture, they cause health hazards due to the release of toxic substances into the environment. Humans and animals are exposed to these chemicals every day through air, water and food. Air and water pollution due to pesticides can result in serious health hazards in humans and animals (Benbrook, Groth, Halloran, Hansen, \& Marquardt, 1996).

Pesticides contribute to increased production of food, feed, and fiber and to their protection from weeds, insect pests, diseases and rodents. However, their poisonous nature gives rise to concern that pesticides also harm human life. The long term effects of low-level doses of pesticide poisons concern many scientists (Bloom \& Degler, 1969). Traces have been found in the flora and fauna around the entire globe, even in remote Antarctica, where pesticides are not used (Bloom \& Degler, 1969). 
The farming community and farm laborers are more vulnerable to health risks due to frequent exposures to pesticides. They are exposed to higher levels of concentrations when engaged in spraying operations. There is the possibility of acute poisoning and long-term effects like cancer. Pesticides can affect the nervous, endocrine, immune and reproductive systems. Infants, young children, and the unborn are more susceptible to the toxic effects of pesticides (Benbrook et al., 1996).

Another problem with indiscriminate pesticide usage is the development of resistance by the pest. Resistance to the crop protection chemicals that we use to control insect pests, weeds and diseases is a major problem of modern agriculture. Growing crops today requires the combined use of novel crop protection products, transgenic plants and integrated management techniques (Clark \& Yamaguchi, 2002).

Pesticide applications kill natural enemies of pest species that normally cause economically insignificant damage (minor pests). Then these minor crop pests become major pest causing pest outbreaks and severe economic losses. This phenomenon is called “secondary pest outbreaks” (Benbrook et al., 1996).

Pesticides also damage useful invertebrates in the soil like earthworms and destroy soil microbial populations that are responsible for maintaining the soil fertility. These loses will impact the soil's ability to sustain life in the long run (Benbrook et al., 1996).

Integrated pest management (IPM) is an effective and environmentally sensitive approach to pest management that relies on a combination of common-sense practices (EPA, 2008). IPM programs use current, comprehensive information on the life cycles of 
pests and their interaction with the environment. This information, in combination with available pest control methods, is used to manage pest damage by the most economical means and with the least possible hazard to people, property, and the environment (EPA, 2008).

Adoption of IPM techniques by the farming community is the most cost effective way of promoting sustainable agriculture. The reliance on pesticides and the associated risks will decline with adoption of IPM methods in pest management (Benbrook et al., 1996).

Zea mays Linnaeus, commonly called corn is widely cultivated in United States in an area of 35 million hectares with a production of 332 million tons (Food and Agricultural Organization, 2008). In 2007, 46,000 acres of corn were grown with a production of 2,997,000 bushels valuing 12,587,000 dollars in West Virginia (National Agricultural Statistical Service, 2008). Corn grain is used for human and animal consumption and as fodder for animals. Corn is also used as roughage or fodder (silage) for dairy and beef cattle (USDA, 2008).

In the United States, corn ranks number one in usage of pesticides. Estimates in 2006 show corn consumed 31\% (in terms of pounds) of the total pesticide usage in the United States. About 115 different kinds of pesticides are used on corn (Alexandre, Nehring, Cornejo \& Grube, 2008).

Statement of Problem

In 1994 the United States Department of Agriculture (USDA) established the National IPM initiative with a goal to expand the adoption of IPM to $75 \%$ of the United 
States crop acreage by the year 2000 (USDA, 2008). To reach this goal, USDA made the state Extension IPM coordinators responsible for promoting and measuring IPM adoption in agriculture (Alston \& Reading, 1998).

According to Baniecki (personal communication, September 10, 2008), the IPM program in West Virginia was started in 1978 with four crops; alfalfa, corn, apples and peaches. Every year, annual reports on IPM programs in these four crops are prepared and submitted to the Federal Government.

However, there is little information available on the extent of adoption of IPM by corn farmers in West Virginia. Such information is essential to develop extension programs on IPM to promote integrated pest management practices to West Virginia corn producers to bring all of them under the IPM umbrella. In this context, the proposed study gathered information on the extent of adoption of IPM practices and the educational needs of corn producers in West Virginia related to pest management.

\section{Purpose of Study}

The purpose of the study was to identify the current management practices adopted by corn producers to control weeds, insect pests and diseases, and assessed the level of adoption of IPM practices by West Virginia corn producers. The study also identified the barriers in the adoption of IPM by corn producers in West Virginia. The research will provide information on the educational needs of the corn farmers in West Virginia that might be useful to researchers and Extension personnel at West Virginia University in designing and developing educational programs on IPM. 


\section{Objectives of Study}

The objectives of the study were:

1. To determine the knowledge of the West Virginia corn producers on integrated pest management practices.

2. To determine the level of adoption of integrated pest management practices by corn producers in West Virginia.

3. To determine the barriers in adoption of integrated pest management by West Virginia corn producers.

4. To determine the educational needs of the West Virginia corn producers on integrated pest management in corn.

\section{Limitations of the study}

This study was limited to corn producers in five West Virginia counties during the 2008 crop year. The county extension agents of the five counties with the largest 2008 corn acreage in West Virginia; Jefferson, Hardy, Mason, Berkeley, and Preston, identified 20 corn producers each from their respective counties. The county agents may have selected corn producers on the basis of who would actually follow-through and fill out the survey. They may have selected producers who practice IPM on their farms or may have chosen farmers who have produced the highest yields in the past years. 


\section{CHAPTER II}

Review of Literature

Integrated pest management (IPM) in agriculture relies primarily on the environmentally friendly processes like the use of pest resistant varieties, the actions of natural enemies and cultural control. IPM increases the sustainability of the farming systems. It improves the social stability of the farming community. IPM is economical as it reduces the dependence of the farming community on procured inputs (FAO, 2008).

Synthetic pesticides were widely available and used in agriculture after the World War II. As a part of agricultural intensification, farmers relied heavily on these synthetic pesticides. This method of plant protection became unsustainable and cost-ineffective due to development of resistance in pests, rising costs of pesticides and negative effects of pesticide in environmental and human health (FAO, 2008).

The first step towards integrated pest management was taken in the early 1940s. In 1942, a wheat variety resistant to Hessian fly was successfully developed for the first time. The concepts of economic thresholds, economic levels and integrated control were introduced in 1959 by V. M. Stern, R. F. Smith, R. van den Bosch and K. S. Hagen. In 1967, the term 'Integrated Pest Management' was introduced by R. F. Smith and R. van den Bosch. The relevance of ecology to IPM through the concept of "Life Systems" was introduced by L. R. Clark, P. W. Geier, R. D. Hughes and R. F. Morris. A biological insecticide Bacillus thuringiensis was released to control lepidopterous pests in 1972 (Dent, 2001). 
The concept of IPM was introduced in1960s by Ray F. Smith, Vernon M. Stern, Robert Van Den Bosh and Harold T. Reynolds of the University of California (USDA, 2008). In 1972, the 6-year Huffakar project was launched with a major objective to develop alternative pest control systems to optimize long-term costs/benefits to both growers and society. Investigators in this project include USDA's Agricultural Research Service, Forest Service, and Cooperative State Research Service, and 19 universities and some private industry segments (USDA, 2008). In 1985, the consortium for IPM expanded in the Huffaker project to include insects, diseases and weeds as pests. The cooperators included USDA, U.S. Environmental Protection Agency, Universities, and the National Science Foundation (USDA, 2008). Evaluation of IPM programs in 15 different states documented benefits that indicated IPM users increased profits by more than $\$ 575$ million annually compared to nonusers. It reported that growers used IPM successfully on cotton, soybeans, corn, vegetables, hay and on external parasites of livestock (USDA, 2008).

Integrated pest management is defined as a management approach that encourages natural control of pest populations by anticipating pest problems and preventing pests from reaching economically damaging levels. All appropriate techniques are used such as enhancing natural enemies, planting pest-resistant crops, adapting cultural management, and using pesticides judiciously (USDA, 2008).

The National Coalition on Integrated Pest Management in 1994 defined IPM as a sustainable approach to managing pests by combining biological, cultural, physical, and chemical tools in a way that minimizes economic, health, and environmental risks (USDA, 2008). 
Pest management, often called as integrated pest management (IPM), is one of the most widely practiced approaches to pest technology in the United States. A survey conducted by A. Vandeman and coworkers (1994) indicated that IPM is being applied on more than half of United States acreage of fruits and nuts, vegetables, and major field crops (corn, soybean, and fall potatoes). A goal is to increase this acreage to $75 \%$. In addition, use of pest management has been shown to reduce pesticide use, cost of production, and risk and to increase yield and profitability (Pedigo, 2002, p. 593 as cited in Norton and Mullen, 1994).

The IPM systems were categorized into four major zones or levels depending on stages of IPM adoption; “No IPM,” "Low level IPM,” "Medium Level IPM” and "Biointensive IPM” (Benbrook et al., 1996). They defined these zones as follows:

"No IPM” systems are largely dependent on pesticides and include few if any preventive practices. Scouting and other practices needed to use pesticides cost-effectively don't constitute “IPM.” They must be accompanied by some preventive measures to move into the "Low IPM" zone.

"Low IPM” systems include scouting and application in accord with economic thresholds, proper timing and operation of spray equipment, and also some preventive practices. Such systems still remain reliant in pesticides to a significant degree.

"Medium level IPM" systems incorporate multi-tactic preventive measures, coupled with efforts to enhance populations of beneficial organisms, especially by cutting back on the use of broad-spectrum and persistent pesticides. Preventive measures assume a major portion of the pest management burden, markedly lessening reliance on pesticides.

"Bio-intensive IPM" systems (also called "High level IPM”) rely primarily on preventive practices that limit pest pressure, diversify and build populations of beneficial organisms, and enhance plant defenses and vigor. Pesticides are used only as a last resort and broad-spectrum, ecologically disruptive products are avoided at all times (Benbrook et al., 1996, p.28).

Corn is the major cash crop grown in the United States of America. It is produced for silage, grain, and seed and as a fresh market produce. The corn grown for feed grain (field corn) occupies the majority of the total corn acreage which accounts to more than 65 million acres (Pedigo, 2002). 
A large complex of insect pests attack corn crop. More than 30 species or species groups causing economic damage in corn. The damage is more significant when corn is grown on the same land continuously. Northern corn rootworm, Western corn rootworm and European corn borer cause the major damage to corn in the North Central Corn Belt. These pests account for most insecticides use in corn fields and they contribute to this crop’s top ranking in the United States for insecticidal use (Pedigo, 2002).

Cultural practices like deep plowing, early planting, crop rotation with soybean and planting resistant varieties has been proven to reduce the insecticidal spraying. Such preventive measures eliminate the need of insecticides completely. However, when outbreaks occur, therapeutic treatments would be required for second-generation corn borers and in susceptible hybrids and for pests like black cutworms (Pedigo, 2002).

There are many constraints to integrated pest management (IPM) adoption on the farm. Drost, Long, Wilson, Miller, and Campbell (1996) reported that time, information, and marketing were important considerations in whether farmers adopt new practices. The IPM practices must be economical. While some IPM practices have become widely used, there are other practices that meet the above criteria and never become accepted by farmers.

Similar research has been done in other areas and on other crops. Malone, Herbert, and Pheasant (2004) reported what IPM practices corn, soybean, and small grain farmers in the coastal plains of Virginia are using and what practices they are not using and the reasons for not using were evaluated. The data indicated that the farmers understand the importance of using IPM practices. The results of the data indicated that 
scouting and use of thresholds were two of the most often used IPM practices. Lack of familiarity, time and resources were the prime reasons for non-use of IPM practices. They concluded that Extension should continuously help farmers learn about IPM and provide IPM refresher courses. They stated that researchers and extension personnel should develop and emphasize IPM programs that are economical and easy to use (Malone, Herbert \& Pheasant, 2004).

The Hatch Act (1887) and the Smith-Lever Act (1914) defined Cooperative Extension Service as the primary educational provider in adult education, especially for the farming community (Seevers, Graham, Gamon \& Conklin, 1997). Cooperative Extension Service is a non-formal educational system that links education and research resources of the United States Department of Agriculture (USDA), land-grant universities, and county administration. The mission of Cooperative Extension Service states that Extension should enable people to improve their lives and communities through learning partnerships that put knowledge to work (Extension Committee in Organizational and Policy, 1995) (Seevers et al., 1997).

According to Trede \& Whittaker (1998), Extension is a vital educational source in adult and continuing education, especially to the agricultural community. The advent of information technology caused knowledge explosion creating a need for unbiased information available through Cooperative Extension Service

The research method using mail questionnaires has been successfully adopted by Long et al., (1996) to assess barriers to adoption of more sustainable practices by farmers 
in Utah. Malone et al., (2004) used the mail questionnaires in determining adoption of integrated pest management practices by grains farmers in Virginia. 


\section{CHAPTER III}

Methodology

Purpose of Study

The purpose of this study was to identify the current management practices adopted by the West Virginia corn producers to control weeds, insect pests, and diseases, and level of adoption of integrated pest management practices. The study also identified the barriers, if any, in the adoption of integrated pest management by corn producers in West Virginia. The research will provide information on the educational needs of the corn farmers in West Virginia that might be useful to researchers and Extension personnel at West Virginia University in designing and developing educational programs on integrated pest management.

Objectives of Study

The objectives of the study were:

1. To determine the knowledge of the West Virginia corn producers on integrated pest management practices.

2. To determine the level of adoption of integrated pest management practices by corn producers in West Virginia.

3. To determine the barriers in adoption of integrated pest management by West Virginia corn producers.

4. To determine the educational needs of the West Virginia corn producers on integrated pest management in corn. 


\section{Research Design}

This study used the descriptive research methodology in education. Descriptive research describes and interprets what is the present condition. It describes relationships that exist, practices that prevail, attitudes, and developing trends. Surveys are one of the important subcategories of descriptive research (Ary, Jacobs \& Razavieh, 1972).

The instrument used in this research was adapted from the model used with grain farmers in Virginia (Malone et al., 2004) and commercial corn and soybean farmers in Illinois (Steffey \& Gary, 2008). The descriptive survey research method was used to collect data from corn producers from the top five corn producing counties in West Virginia via a mail questionnaire. "Survey method of research is an appropriate mode of inquiry whenever it makes good sense to conceptualize what is being studied as essentially a distinct population of basically similar objects” (Simmons \& McCall., 1985, p. 119-120). The basic aims of survey research are in fact to statistically describe and explain the level of adoption of integrated pest management among the selected populations.

\section{Population}

The target population in this study was 2008 West Virginia corn producers. According to the best estimates of West Virginia University agricultural extension specialists, the total population was determined to be 1500 . 
Sample

The purposeful sample size was determined to be 100. The top five corn producing counties: Jefferson, Hardy, Mason, Berkeley and Preston in the year 2008 were selected for this survey. These five counties account for $66.8 \%$ of the 2008 corn acreage in West Virginia. Twenty corn producers from each county were identified with the help of the county extension agent. Data for this research have been obtained through a survey of these farmers. These five counties received 20 surveys each, for a total of 100 surveys.

Instrumentation

A mail questionnaire was used to collect data for this study. Mail questionnaires are an effective way of collecting large amounts of information at a low cost per respondent. No interviewer is involved to bias the respondents’ answers. However, mail questionnaires also have some disadvantages. They are not flexible and require simple and clearly worded questions. Mail surveys usually take longer time to complete and some questions may be misinterpreted by the respondents. The number of people returning the questionnaire (response rate) is often very low (Kotler \& Armstrong, 1991).

Adequate care was taken to prepare the mail questionnaire. The questions were written in simple language and were clearly worded. Necessary steps were adopted to improve the response rate of the mailed questionnaire. The Dillman’s Tailored Design Method was used to mitigate low response rate (Dillman, 2000).

The survey consisted of six parts. Part I of the survey inquired about general aspects of pesticides and their impact on environment. Part II, III and IV of the survey 
inquired about the current pest management adoption trends and barriers in adoption of IPM in weeds, insect pests and diseases respectively and their educational needs on IPM. Part $\mathrm{V}$ was designed to document level of adoption of IPM practices by corn producers in West Virginia. Part VI of the survey documents the demographic information of the participants. A cover letter signed by the researcher and the committee chairman, explained the purpose of the study and gave directions for completing the questionnaire. A self-addressed stamped envelope was included to help encourage the return of the instrument.

The face and content validity of the instrument used in the study was established by presenting it to a panel of experts from West Virginia University consisting of faculty members and extension specialist in integrated pest management with extensive professional, teaching, and research in agriculture. The instrument was deemed valid for use in measuring concepts relative to integrated pest management and agriculture literacy.

The total data were used to establish the reliability of the instrument. The questionnaire was divided into two segments and the Spearman - Brown split-half statistical procedure was used to establish the reliability of the instrument. The reliability of the instrument was found to be exemplary at 0.68 and 0.86 for part 1 and part 2 respectively (Robinson, Shaver, \& Wrightsman, 1991).

\section{Data Collection}

The Extension agents in the five top corn producing counties in West Virginia were requested to provide the researcher a list of 20 farmers and their mailing addresses. 
A packet containing the questionnaire accompanied by a letter of introduction signed by the graduate student and the chairman of the research study committee along with a selfaddressed stamped envelope to return the questionnaire was sent to each of the participants.

The following steps were taken to improve the response rate. The questionnaires were printed as a booklet on colored pastel paper (Dillman, 2000). The Dillman's Tailored Design Method was used to enhance the response rate. A pre-notice letter was sent to the respondent a few days prior to the questionnaire informing subjects they will receive the questionnaire. A week later, the initial mailing packet containing the cover letter, instrument and self-addressed envelope was sent to each of the respondents. Two weeks later a follow-up post card was send after the deadline as a reminder to complete the survey. A second mailing was sent to the non-respondents containing the cover letter, instrument and a stamped self-addressed envelope. A follow-up post card was send after a week. A thank you letter was sent to all the respondents in appreciation of their time and effort (Dillman, 2000).

Non-response error was addressed by comparing the data of the early and late respondents. Significant differences were not found between the early and late respondents. Therefore generalizations could be made to the accessible population.

\section{Data Analysis}

The study sought to determine the pest management practices, barriers in adoption of integrated pest management, and the educational needs of the West Virginia corn producers. Statistical tools like frequencies and percentages were used to analyze the 
data. The score on Part V of the survey was used to categorize West Virginia corn producers into four categories, “No IPM” (score 1-3), “Low IPM” (score 4-6), “Medium Level IPM” (score 7-9), and "Bio-intensive IPM” (score 10-12).

Use of Findings

Findings from this research study may be used by the researchers and West Virginia Extension Service in developing of educational programs on IPM in future. These finding can also be used by the county extension agents in developing educational programs on IPM to reduce the use of pesticides and to improve productivity of corn. 


\section{CHAPTER IV}

\section{Findings}

Purpose of the Study

The purpose of this research study was to provide information to the West Virginia Extension Service that may be useful in designing and developing educational programs on integrated pest management. To accomplish this, a purposeful sample of 100 corn producers were surveyed for their knowledge on integrated pest management practices, the barriers in adoption of integrated pest management and the educational needs of West Virginia corn producers on integrated pest management. The aggregate response rate from this sample was $64 \%$.

\section{Objectives of the Study}

The objectives of the study were:

1. To determine the knowledge of the West Virginia corn producers on integrated pest management practices.

2. To determine the level of adoption of integrated pest management practices by corn producers in West Virginia.

3. To determine the barriers in adoption of integrated pest management by West Virginia corn producers.

4. To determine the educational needs of the West Virginia corn producers on integrated pest management in corn.

Responses of West Virginia corn producers were summarized and results of the data analysis are presented in the following areas: demographics of the respondents, general 
perception of the respondents on pesticide usage, weed management, disease management and pest management. The score on Part V of the survey was used to categorize West Virginia corn producers into four categories, “No IPM” (score 1-3), “Low IPM” (score 4-6), "Medium Level IPM” (score 7-9), and "Bio-intensive IPM” (score 10-12). Data obtained from this study were analyzed by frequencies and percentages. Correlation among various demographic variables and IPM adoption levels of West Virginia corn producers were attempted but none of them were found significant.

Counties Represented by Corn Producers to IPM Survey

Questionnaires were mailed to 20 participants of the five top corn producing counties in West Virginia. All the respondents were asked to identify their county. Eighteen (28.1\%) respondents identified their county as Jefferson. Thirteen (20.3\%) respondents identified their county as Hardy. Ten (15.6\%) respondents identified their county as Berkeley. There were 12 (18.8\%) respondents each for Mason and Preston counties (see Table 1).

Table 1

Counties Represented by Corn Producers to IPM Survey ${ }^{1}$

\begin{tabular}{lcc}
\hline & $\mathrm{N}$ & $\%$ \\
\hline Jefferson & 18 & 28.1 \\
Hardy & 13 & 20.3 \\
Mason & 12 & 18.8 \\
Berkeley & 10 & 15.6 \\
Preston & 12 & 18.8 \\
${ }^{1} \mathrm{~N}=65$ because one respondent reported corn production in two counties.
\end{tabular}


Gender of WV Corn Producers

Respondents were asked to identify their gender. One respondent (1.6\%) was female while 63 (98.4\%) respondents were male (see Table 2).

Table 2

Gender of WV Corn Producers

\begin{tabular}{lcc}
\hline & $\mathrm{N}$ & $\%$ \\
\hline Male & 63 & 98.4 \\
Female & 1 & 1.6 \\
\hline
\end{tabular}

Age of WV Corn Producers

Respondents were asked to identify their age using five categories. One (1.6\%) individual indicated the age to be in the 21-30 years category. Sixteen (25\%) respondents listed their age in the 41-50 years category. Forty-seven (73.4\%) respondents identified their age to be in the above 50 years category (see Table 3).

Table 3

Age of WV Corn Producers

\begin{tabular}{lcc}
\hline & $\mathrm{N}$ & $\%$ \\
\hline $21-30$ years & 1 & 1.6 \\
$41-50$ years & 16 & 25.0 \\
Above 50 years & 47 & 73.4 \\
\hline
\end{tabular}


Acreage of Corn Grown in 2008 by IPM Survey Respondents

The respondents were asked to indicate the number of acres of corn grown in 2008 using six categories. Eighteen (28.1\%) of the respondents indicated their area of corn grown in 2008 was below 50 acres. Ten (15.6\%) of the respondents listed their acreage in the 50-100 acres category. Twelve (18.8\%) respondents indicated the area of corn grown in 2008 was 100-150 acres. Three (4.7\%) respondents listed their acreage of corn in 2008 to be $150-200$ acres. Four (6.3\%) respondents indicated the area of corn grown was 200-250 acres. Seventeen (26.6\%) respondents listed acreage of corn in 2008 at above 250 acres (see Table 4).

Table 4

Acreage of Corn Grown in 2008 by IPM Survey Respondents

\begin{tabular}{lcc}
\hline & $\mathrm{N}$ & $\%$ \\
\hline Below 50 acres & 18 & 28.1 \\
$50-100$ acres & 10 & 15.6 \\
$100-150$ acres & 12 & 18.8 \\
$150-200$ acres & 3 & 4.7 \\
$200-250$ acres & 4 & 6.3 \\
Above 250 acres & 17 & 26.6 \\
\hline
\end{tabular}

Highest Level of Education for WV Corn Producers

All the respondents were asked to indicate their highest level of education using six categories. One (1.6\%) individual indicated they had a less than high school 
education. Thirty (46.9\%) respondents identified their highest level of education as a high school graduate. Eight (12.5\%) of the respondents indicated their level of education as some college. Five (7.8\%) of the respondents listed their level of education as a two-year college degree associate. Seventeen (26.6\%) of the participants declared their level of education in the four-year college degree - Bachelor's category. Three $(4.7 \%)$ of the respondents indicated their highest level of education as a graduate degree - Master's or Doctoral (see Table 5).

Table 5

Highest Level of Education for WV Corn Producers

\begin{tabular}{lcc}
\hline & $\mathrm{N}$ & $\%$ \\
\hline $\begin{array}{l}\text { Less than high school } \\
\text { graduate }\end{array}$ & 1 & 1.6 \\
$\begin{array}{l}\text { High school graduate } \\
\text { Some college }\end{array}$ & 30 & 46.9 \\
$\begin{array}{l}\text { Two-year college degree - } \\
\text { Associate's }\end{array}$ & 8 & 12.5 \\
$\begin{array}{l}\text { Four-year college degree - } \\
\text { Bachelor's }\end{array}$ & 5 & 7.8 \\
$\begin{array}{l}\text { Graduate degree - Master's or } \\
\text { Doctorate }\end{array}$ & 17 & 26.6 \\
\hline
\end{tabular}

Agricultural Classes in High School and IPM Training(s) Attended by WV Corn Producers

The respondents were asked to indicate whether they took agricultural classes in high school and if they attended IPM training(s). Forty-five (70.3\%) of the respondents 
indicated they took agricultural classes in high school. Thirty-six (57.1\%) of the respondents indicated they had attended IPM training(s) (see Table 6).

Table 6

Agricultural Classes in High School and IPM Training(s) Attended by WV Corn

Producers

$\mathrm{N} \quad \%$

Did you take agricultural

classes in high school?

45

70.3

Have you attended IPM

training(s)?

36

57.1

Responses to the Questionnaire

Respondents in the study were instructed to rate their opinion on a six point Likert scale by circling the letters in the box that best corresponds to their response. The questions were grouped into five parts: general perception, weed management, disease management, pest management which was sub-categorized into scouting for insects, cutworms, European corn borer, armyworms, wireworms and white grubs. Part V consisted of 12 statements and the respondents were instructed to indicate their opinion by putting check marks in the box that best corresponds to their response. The score on Part V of the survey was used to categorize West Virginia corn producers into four categories, “No IPM” (score 1-3), “Low IPM” (score 4-6), “Medium Level IPM” (score 7-9), and "Bio-intensive IPM” (score 10-12). 


\section{General Perception of WV Corn Producers on Pesticide Usage}

Within the general group, there were 16 statements. The first statement “Agriculture chemicals are vital for good crop yields,” to which 64 (100\%) respondents agreed (see Table 7).

Twenty-four (37.5\%) respondents agreed with the statement "Chemicals used in agriculture cause air pollution” while 40 (62.5\%) respondents disagreed. Thirty-two (50\%) respondents agreed with the statement "Chemicals used in agriculture cause water pollution” (see Table 7).

Sixty-three (98.4\%) respondents agreed with the statement, "Repeated use of herbicides with the same mode of action may lead to resistance biotypes of weeds.” Sixty-two (96.9\%) respondents agreed with the statement "Repeated use of insecticides with the same mode of action may lead to resistance in biotypes of insects” (see Table 7).

Sixty-one (95.2\%) respondents agreed with the statements, “Crop rotation is good method to control weed population" and "Crop rotation is good method of control insect pest populations.” Sixty (93.8\%) respondents agreed with the statement “Crop rotation reduces the crop damage due to diseases” (see Table 7).

Fifty-five (87.3\%) respondents disagreed with the statement “All insects seen on the crop cause damage to crops.” Fifty-nine (92.2\%) respondents agreed with the statement "Use of Bt-Corn reduces the number of sprayings against insect pests" (see Table 7).

Fifty-two (81.3\%) respondents agreed with the statement "Exposure to pesticides results in serious health problems” while 12 (18.7\%) respondents disagreed. Sixty-four 
(100\%) respondents agreed with the statement "Protection gear should be worn while spraying pesticides" (see Table 7).

Sixty-one (95.2\%) respondents agreed with the statement, "No pesticide should be applied within 30 meters of a well used for domestic purpose.” Fifty-four (84.1\%) respondents agreed with the statement "The speed of spray vehicle should not exceed 10 miles/hour while spraying” (see Table 7).

Sixty-four (100\%) respondents agreed with the statement "Seed treatment with fungicide helps in reducing the soil borne diseases in corn.” Forty-six (71.9\%) respondents agreed with the statement "There are other methods than chemicals to control pests in corn” while 18 (28.1\%) respondents disagreed (see Table 7). 
Table 7

General Perception of WV Corn Producers on Pesticide Usage

\begin{tabular}{|c|c|c|c|c|c|c|c|c|c|c|c|c|}
\hline & \multicolumn{2}{|c|}{$\begin{array}{l}\text { Disagree } \\
\text { Strongly }\end{array}$} & \multicolumn{2}{|c|}{ Disagree } & \multicolumn{2}{|c|}{$\begin{array}{l}\text { Slightly } \\
\text { Disagree }\end{array}$} & \multicolumn{2}{|c|}{$\begin{array}{l}\text { Slightly } \\
\text { Agree }\end{array}$} & \multicolumn{2}{|c|}{ Agree } & \multicolumn{2}{|c|}{$\begin{array}{l}\text { Agree } \\
\text { Strongly }\end{array}$} \\
\hline & $\mathrm{N}$ & $\%$ & $\mathrm{~N}$ & $\%$ & $\mathrm{~N}$ & $\%$ & $\mathrm{~N}$ & $\%$ & $\mathrm{~N}$ & $\%$ & $\mathrm{~N}$ & $\%$ \\
\hline $\begin{array}{l}\text { Agriculture chemicals are vital for } \\
\text { good crop yields }\end{array}$ & 0 & .0 & 0 & .0 & 0 & .0 & 3 & 4.7 & 25 & 39.1 & 36 & 56.3 \\
\hline $\begin{array}{l}\text { Chemicals used in agriculture cause air } \\
\text { pollution }\end{array}$ & 9 & 14.1 & 17 & 26.6 & 14 & 21.9 & 15 & 23.4 & 6 & 9.4 & 3 & 4.7 \\
\hline $\begin{array}{l}\text { Chemicals used in agriculture cause } \\
\text { water pollution }\end{array}$ & 4 & 6.3 & 14 & 22.2 & 13 & 20.6 & 18 & 28.6 & 10 & 15.9 & 4 & 6.3 \\
\hline $\begin{array}{l}\text { Repeated use of herbicides with the } \\
\text { same mode of action may lead to } \\
\text { resistance biotypes of weeds }\end{array}$ & 0 & .0 & 0 & .0 & 1 & 1.6 & 3 & 4.7 & 43 & 67.2 & 17 & 26.6 \\
\hline $\begin{array}{l}\text { Crop rotation is good method to } \\
\text { control weed population }\end{array}$ & 1 & 1.6 & 1 & 1.6 & 1 & 1.6 & 2 & 3.1 & 37 & 57.8 & 22 & 34.4 \\
\hline $\begin{array}{l}\text { All insects seen on the crop cause } \\
\text { damage to crops }\end{array}$ & 15 & 23.8 & 34 & 54.0 & 6 & 9.5 & 3 & 4.8 & 3 & 4.8 & 2 & 3.2 \\
\hline
\end{tabular}


Table 7 (Continued)

General Perception of WV Corn Producers on Pesticide Usage

\begin{tabular}{|c|c|c|c|c|c|c|c|c|c|c|c|c|}
\hline & \multicolumn{2}{|c|}{$\begin{array}{l}\text { Disagree } \\
\text { Strongly }\end{array}$} & \multicolumn{2}{|c|}{ Disagree } & \multicolumn{2}{|c|}{$\begin{array}{l}\text { Slightly } \\
\text { Disagree }\end{array}$} & \multicolumn{2}{|c|}{$\begin{array}{l}\text { Slightly } \\
\text { Agree }\end{array}$} & \multicolumn{2}{|c|}{ Agree } & \multicolumn{2}{|c|}{$\begin{array}{l}\text { Agree } \\
\text { Strongly }\end{array}$} \\
\hline & $\mathrm{N}$ & $\%$ & $\mathrm{~N}$ & $\%$ & $\mathrm{~N}$ & $\%$ & $\mathrm{~N}$ & $\%$ & $\mathrm{~N}$ & $\%$ & $\mathrm{~N}$ & $\%$ \\
\hline $\begin{array}{l}\text { Repeated use of insecticides with the } \\
\text { same mode of action may lead to } \\
\text { resistance in biotypes of insects }\end{array}$ & 0 & .0 & 0 & .0 & 2 & 3.1 & 9 & 14.1 & 40 & 62.5 & 13 & 20.3 \\
\hline $\begin{array}{l}\text { Crop rotation is good method of } \\
\text { control insect pest populations }\end{array}$ & 1 & 1.6 & 1 & 1.6 & 1 & 1.6 & 11 & 17.2 & 31 & 48.4 & 19 & 29.7 \\
\hline $\begin{array}{l}\text { Exposure to pesticides results in } \\
\text { serious health problems }\end{array}$ & 4 & 6.3 & 6 & 9.4 & 2 & 3.1 & 17 & 26.6 & 21 & 32.8 & 14 & 21.9 \\
\hline $\begin{array}{l}\text { Use of Bt-Corn reduces the number of } \\
\text { sprayings against insect pests }\end{array}$ & 0 & .0 & 1 & 1.6 & 4 & 6.3 & 5 & 7.8 & 35 & 54.7 & 19 & 29.7 \\
\hline $\begin{array}{l}\text { Protection gear should be worn while } \\
\text { spraying pesticides }\end{array}$ & 0 & .0 & 0 & .0 & 0 & .0 & 3 & 4.7 & 20 & 31.3 & 41 & 64.1 \\
\hline $\begin{array}{l}\text { No pesticide should be applied within } \\
30 \text { meters of well used for domestic } \\
\text { purpose }\end{array}$ & 0 & .0 & 2 & 3.2 & 1 & 1.6 & 3 & 4.8 & 23 & 36.5 & 34 & 54.0 \\
\hline
\end{tabular}


Table 7 (Continued)

General Perception of WV Corn Producers on Pesticide Usage

\begin{tabular}{|c|c|c|c|c|c|c|c|c|c|c|c|c|}
\hline & \multicolumn{2}{|c|}{$\begin{array}{l}\text { Disagree } \\
\text { Strongly }\end{array}$} & \multicolumn{2}{|c|}{ Disagree } & \multicolumn{2}{|c|}{$\begin{array}{l}\text { Slightly } \\
\text { Disagree }\end{array}$} & \multicolumn{2}{|c|}{$\begin{array}{l}\text { Slightly } \\
\text { Agree }\end{array}$} & \multicolumn{2}{|c|}{ Agree } & \multicolumn{2}{|c|}{$\begin{array}{l}\text { Agree } \\
\text { Strongly }\end{array}$} \\
\hline & $\mathrm{N}$ & $\%$ & $\mathrm{~N}$ & $\%$ & $\mathrm{~N}$ & $\%$ & $\mathrm{~N}$ & $\%$ & $\mathrm{~N}$ & $\%$ & $\mathrm{~N}$ & $\%$ \\
\hline $\begin{array}{l}\text { The speed of spray vehicle should not } \\
\text { exceed } 10 \text { miles/hour }\end{array}$ & 2 & 3.2 & 4 & 6.3 & 4 & 6.3 & 9 & 14.3 & 32 & 50.8 & 12 & 19.0 \\
\hline $\begin{array}{l}\text { Crop rotation reduces the crop damage } \\
\text { due to diseases }\end{array}$ & 0 & .0 & 2 & 3.1 & 2 & 3.1 & 6 & 9.4 & 37 & 57.8 & 17 & 26.6 \\
\hline $\begin{array}{l}\text { Seed treatment with fungicide helps in } \\
\text { reducing the soil borne diseases in } \\
\text { corn }\end{array}$ & 0 & .0 & 0 & .0 & 0 & .0 & 9 & 14.1 & 40 & 62.5 & 15 & 23.4 \\
\hline $\begin{array}{l}\text { There are other methods than } \\
\text { chemicals to control pests in corn }\end{array}$ & 1 & 1.6 & 6 & 9.4 & 11 & 17.2 & 14 & 21.9 & 25 & 39.1 & 7 & 10.9 \\
\hline
\end{tabular}


Weed Management Techniques used by WV Corn Producers

The participants in this section were instructed to indicate their responses on weed management in corn. Part II of the questionnaire consisted of 11 statements.

Forty-eight (75\%) respondents agreed with the statement "I am confident in my weed identification skills.” Thirty (46.8\%) respondents agreed with the statement "I have adequate time to scout for weeds” while 34 (53.2\%) respondents disagreed. Fifty (79.4\%) respondents agreed with the statement "I personally scout for weeds in my corn.” Fortyseven (74.6\%) respondents disagreed with the statement "Scouting for weeds requires too much walking” while 16 (25.4\%) agreed (see Table 8).

Fifty-four (85.7\%) respondents disagreed with the statement "I cultivate to control weeds in corn” while nine (14.2\%) respondents agreed. Fifty-seven (90.5\%) respondents disagreed with the statement "Cultivation adequately controls weeds in my corn." Thirtytwo (52.4\%) respondents agreed with the statement "Corn gets too tall for me to cultivate effectively” while 29 (47.6\%) respondents disagreed (see Table 8).

Fifty-five (85.9\%) respondents disagreed with the statement "I make paper or computer maps of weed hotspots in my cornfields” while nine (14.1\%) respondents agreed. Sixty-two (96.9\%) respondents agreed with the statement "I rely more on herbicides than cultivation to control weeds in corn” (see Table 8).

Forty-seven (73.5\%) respondents agreed with the statement "I need more information on Scouting for weeds in corn” while 17 (26.5\%) respondents disagreed. Forty (62.5\%) respondents disagreed with the statement "I need more information on weed management by cultivation” while 24 (37.5\%) respondents agreed (see Table 8). 
Table 8

Weed Management by WV Corn Producers

\begin{tabular}{|c|c|c|c|c|c|c|c|c|c|c|c|c|}
\hline & \multicolumn{2}{|c|}{$\begin{array}{l}\text { Disagree } \\
\text { Strongly }\end{array}$} & \multicolumn{2}{|c|}{ Disagree } & \multicolumn{2}{|c|}{$\begin{array}{l}\text { Slightly } \\
\text { Disagree }\end{array}$} & \multicolumn{2}{|c|}{$\begin{array}{l}\text { Slightly } \\
\text { Agree }\end{array}$} & \multicolumn{2}{|c|}{ Agree } & \multicolumn{2}{|c|}{$\begin{array}{l}\text { Agree } \\
\text { Strongly }\end{array}$} \\
\hline & $\mathrm{N}$ & $\%$ & $\mathrm{~N}$ & $\%$ & $\mathrm{~N}$ & $\%$ & $\mathrm{~N}$ & $\%$ & $\mathrm{~N}$ & $\%$ & $\mathrm{~N}$ & $\%$ \\
\hline $\begin{array}{l}\text { I am confident in my weed } \\
\text { identification skills }\end{array}$ & 2 & 3.1 & 6 & 9.4 & 8 & 12.5 & 19 & 29.7 & 23 & 35.9 & 6 & 9.4 \\
\hline $\begin{array}{l}\text { I have adequate time to scout for } \\
\text { weeds }\end{array}$ & 6 & 9.4 & 12 & 18.8 & 16 & 25.0 & 14 & 21.9 & 13 & 20.3 & 3 & 4.7 \\
\hline $\begin{array}{l}\text { I personally scout for weeds in my } \\
\text { corn }\end{array}$ & 2 & 3.2 & 4 & 6.3 & 7 & 11.1 & 18 & 28.6 & 27 & 42.9 & 5 & 7.9 \\
\hline I cultivate to control weeds in corn & 23 & 36.5 & 28 & 44.4 & 3 & 4.8 & 5 & 7.9 & 4 & 6.3 & 0 & .0 \\
\hline $\begin{array}{l}\text { Cultivation adequately controls weeds } \\
\text { in my corn }\end{array}$ & 25 & 39.7 & 25 & 39.7 & 7 & 11.1 & 4 & 6.3 & 2 & 3.2 & 0 & .0 \\
\hline $\begin{array}{l}\text { Corn gets too tall for me to cultivate } \\
\text { effectively }\end{array}$ & 10 & 16.4 & 15 & 24.6 & 4 & 6.6 & 6 & 9.8 & 19 & 31.1 & 7 & 11.5 \\
\hline $\begin{array}{l}\text { Scouting for weeds requires too much } \\
\text { walking }\end{array}$ & 13 & 20.6 & 27 & 42.9 & 7 & 11.1 & 7 & 11.1 & 7 & 11.1 & 2 & 3.2 \\
\hline
\end{tabular}


Table 8 (Continued)

Weed Management by WV Corn Producers

\begin{tabular}{|c|c|c|c|c|c|c|c|c|c|c|c|c|}
\hline & \multicolumn{2}{|c|}{$\begin{array}{l}\text { Disagree } \\
\text { Strongly }\end{array}$} & \multicolumn{2}{|c|}{ Disagree } & \multicolumn{2}{|c|}{$\begin{array}{l}\text { Slightly } \\
\text { Disagree }\end{array}$} & \multicolumn{2}{|c|}{$\begin{array}{l}\text { Slightly } \\
\text { Agree }\end{array}$} & \multicolumn{2}{|c|}{ Agree } & \multicolumn{2}{|c|}{$\begin{array}{l}\text { Agree } \\
\text { Strongly }\end{array}$} \\
\hline & $\mathrm{N}$ & $\%$ & $\mathrm{~N}$ & $\%$ & $\mathrm{~N}$ & $\%$ & $\mathrm{~N}$ & $\%$ & $\mathrm{~N}$ & $\%$ & $\mathrm{~N}$ & $\%$ \\
\hline $\begin{array}{l}\text { I make paper or computer maps of } \\
\text { weed hotspots in my cornfields }\end{array}$ & 17 & 26.6 & 34 & 53.1 & 4 & 6.3 & 6 & 9.4 & 2 & 3.1 & 1 & 1.6 \\
\hline $\begin{array}{l}\text { I rely more on herbicides than } \\
\text { cultivation to control weeds in corn }\end{array}$ & 2 & 3.1 & 0 & .0 & 0 & .0 & 2 & 3.1 & 28 & 43.8 & 32 & 50.0 \\
\hline $\begin{array}{l}\text { I need more information on Scouting } \\
\text { for weeds in corn }\end{array}$ & 4 & 6.3 & 7 & 10.9 & 6 & 9.4 & 17 & 26.6 & 27 & 42.2 & 3 & 4.7 \\
\hline $\begin{array}{l}\text { I need more information on weed } \\
\text { management by cultivation }\end{array}$ & 10 & 15.6 & 19 & 29.7 & 11 & 17.2 & 11 & 17.2 & 10 & 15.6 & 3 & 4.7 \\
\hline
\end{tabular}




\section{Disease Management Techniques used by WV Corn Producers}

The participants in this section were instructed to indicate their responses on weed management in corn. Part III of the questionnaire consisted of nine statements.

Forty-four (68.8\%) respondents disagreed with the statement "I am confident in my disease identification skills” while 20 (31.3\%) respondents disagreed. Forty-three (67.2\%) respondents disagreed with the statement "I have adequate time to scout for diseases” while 21 (32.9\%) respondents disagreed. Thirty-six (56.3\%) respondents agreed with the statement "I scout for diseases in my corn" while 28 (43.7\%) respondents disagreed (see Table 9).

Fifty-nine (85.7\%) respondents agreed with the statement “I select corn seed treated with fungicides." Sixty-three (98.4\%) respondents disagreed with the statement "I select disease-resistant corn varieties” (see Table 9).

Fifty (78.1\%) respondents agreed with the statement "Scouting for diseases helps me decide if I need to rotate future crops to avoid diseases.” Forty-nine (76.5\%) respondents agreed with the statement "I need more information on scouting for diseases in corn” while 15 (23.5\%) disagreed. Fifty-five (87.2\%) respondents agreed with the statement "I need more information on seed treatment to control diseases” while eight (12.8\%) respondents disagreed with the statement and 55 (87.3\%) respondents agreed with the statement "I need more information on disease management of corn” (see Table 9). 
Table 9

Disease Management by WV Corn Producers

\begin{tabular}{|c|c|c|c|c|c|c|c|c|c|c|c|c|}
\hline & \multicolumn{2}{|c|}{$\begin{array}{l}\text { Disagree } \\
\text { Strongly }\end{array}$} & \multicolumn{2}{|c|}{ Disagree } & \multicolumn{2}{|c|}{$\begin{array}{l}\text { Slightly } \\
\text { Disagree }\end{array}$} & \multicolumn{2}{|c|}{$\begin{array}{l}\text { Slightly } \\
\text { Agree }\end{array}$} & \multicolumn{2}{|c|}{ Agree } & \multirow{2}{*}{$\begin{array}{c}\text { Agree } \\
\mathrm{N}\end{array}$} & \multirow{2}{*}{$\begin{array}{c}\text { Strongly } \\
\%\end{array}$} \\
\hline & $\mathrm{N}$ & $\%$ & $\mathrm{~N}$ & $\%$ & $\mathrm{~N}$ & $\%$ & $\mathrm{~N}$ & $\%$ & $\mathrm{~N}$ & $\%$ & & \\
\hline $\begin{array}{l}\text { I am confident in my disease } \\
\text { identification skills }\end{array}$ & 4 & 6.3 & 27 & 42.2 & 13 & 20.3 & 10 & 15.6 & 9 & 14.1 & 1 & 1.6 \\
\hline $\begin{array}{l}\text { I have adequate time to scout for } \\
\text { diseases }\end{array}$ & 8 & 12.5 & 24 & 37.5 & 11 & 17.2 & 8 & 12.5 & 12 & 18.8 & 1 & 1.6 \\
\hline I scout for diseases in my corn & 7 & 10.9 & 11 & 17.2 & 10 & 15.6 & 16 & 25.0 & 17 & 26.6 & 3 & 4.7 \\
\hline $\begin{array}{l}\text { I select corn seed treated with } \\
\text { fungicides }\end{array}$ & 0 & .0 & 3 & 4.7 & 2 & 3.1 & 11 & 17.2 & 37 & 57.8 & 11 & 17.2 \\
\hline I select disease-resistant corn varieties & 0 & .0 & 0 & .0 & 1 & 1.6 & 3 & 4.7 & 45 & 70.3 & 15 & 23.4 \\
\hline $\begin{array}{l}\text { Scouting for diseases helps me decide } \\
\text { if I need to rotate future crops to avoid } \\
\text { diseases }\end{array}$ & 3 & 4.7 & 7 & 10.9 & 4 & 6.3 & 17 & 26.6 & 31 & 48.4 & 2 & 3.1 \\
\hline $\begin{array}{l}\text { I need more information on scouting } \\
\text { for diseases in corn }\end{array}$ & 0 & .0 & 9 & 14.1 & 6 & 9.4 & 13 & 20.3 & 31 & 48.4 & 5 & 7.8 \\
\hline
\end{tabular}


Table 9 (Continued)

Disease Management by WV Corn Producers

\begin{tabular}{|c|c|c|c|c|c|c|c|c|c|c|c|c|}
\hline & \multicolumn{2}{|c|}{$\begin{array}{l}\text { Disagree } \\
\text { Strongly }\end{array}$} & \multicolumn{2}{|c|}{ Disagree } & \multicolumn{2}{|c|}{$\begin{array}{l}\text { Slightly } \\
\text { Disagree }\end{array}$} & \multicolumn{2}{|c|}{$\begin{array}{c}\text { Slightly } \\
\text { Agree }\end{array}$} & \multicolumn{2}{|c|}{ Agree } & \multicolumn{2}{|c|}{ Agree Strongly } \\
\hline & $\mathrm{N}$ & $\%$ & $\mathrm{~N}$ & $\%$ & $\mathrm{~N}$ & $\%$ & $\mathrm{~N}$ & $\%$ & $\mathrm{~N}$ & $\%$ & $\mathrm{~N}$ & $\%$ \\
\hline $\begin{array}{l}\text { I need more information on seed } \\
\text { treatment to control diseases }\end{array}$ & 0 & .0 & 4 & 6.3 & 4 & 6.3 & 12 & 19.0 & 37 & 58.7 & 6 & 9.5 \\
\hline $\begin{array}{l}\text { I need more information on disease } \\
\text { management of corn }\end{array}$ & 0 & .0 & 4 & 6.3 & 4 & 6.3 & 10 & 15.9 & 40 & 63.5 & 5 & 7.9 \\
\hline
\end{tabular}




\section{Pest Management Practices used by WV Corn Producers}

The participants in this section were instructed to indicate their responses on pest management in corn. Part IV of the questionnaire consisted of six sub-divisions namely scouting for insects, cutworms, European corn borer, armyworms, wireworms and white grubs.

Scouting for Insects by WV Corn Producers

The first sub-division in the pest management consisted of six questions on scouting for insects for pest management. Forty-one (64.1\%) respondents agreed with the statement “I personally scout my corn for insects” while 23 (35.9\%) respondents disagreed. Fifty-two (81.2\%) respondents disagreed with the statement “An Extension Agent scouts my corn for insects.” Thirty-eight (59.4\%) respondents disagreed with the statement “An independent crop consultant scouts my corn for insects” (see Table 10).

Thirty-eight (59.4\%) respondents disagreed with the statement "Scouting for insects requires too much time” while 26 (40.6\%) respondents disagreed. Forty-nine (76.5\%) respondents disagreed with the statement "Scouting for insects requires too much walking." Fifty-five (86\%) respondents disagreed with the statement "Scouting for insects costs too much” (see Table 10). 
Table 10

Scouting for Insects by WV Corn Producers

\begin{tabular}{|c|c|c|c|c|c|c|c|c|c|c|c|c|}
\hline & \multicolumn{2}{|c|}{$\begin{array}{l}\text { Disagree } \\
\text { Strongly }\end{array}$} & \multicolumn{2}{|c|}{ Disagree } & \multicolumn{2}{|c|}{$\begin{array}{l}\text { Slightly } \\
\text { Disagree }\end{array}$} & \multicolumn{2}{|c|}{$\begin{array}{l}\text { Slightly } \\
\text { Agree }\end{array}$} & \multicolumn{2}{|c|}{ Agree } & \multicolumn{2}{|c|}{$\begin{array}{c}\text { Agree } \\
\text { Strongly }\end{array}$} \\
\hline & $\mathrm{N}$ & $\%$ & $\mathrm{~N}$ & $\%$ & $\mathrm{~N}$ & $\%$ & $\mathrm{~N}$ & $\%$ & $\mathrm{~N}$ & $\%$ & $\mathrm{~N}$ & $\%$ \\
\hline I personally scout my corn for insects & 5 & 7.8 & 16 & 25.0 & 2 & 3.1 & 17 & 26.6 & 22 & 34.4 & 2 & 3.1 \\
\hline $\begin{array}{l}\text { An Extension Agent scouts my corn } \\
\text { for insects }\end{array}$ & 16 & 25.0 & 31 & 48.4 & 5 & 7.8 & 9 & 14.1 & 2 & 3.1 & 1 & 1.6 \\
\hline $\begin{array}{l}\text { An independent crop consultant scouts } \\
\text { my corn for insects }\end{array}$ & 14 & 21.9 & 17 & 26.6 & 7 & 10.9 & 7 & 10.9 & 15 & 23.4 & 4 & 6.3 \\
\hline $\begin{array}{l}\text { Scouting for insects requires too much } \\
\text { time }\end{array}$ & 6 & 9.4 & 22 & 34.4 & 10 & 15.6 & 11 & 17.2 & 13 & 20.3 & 2 & 3.1 \\
\hline $\begin{array}{l}\text { Scouting for insects requires too much } \\
\text { walking }\end{array}$ & 13 & 20.3 & 23 & 35.9 & 13 & 20.3 & 9 & 14.1 & 5 & 7.8 & 1 & 1.6 \\
\hline Scouting for insects costs too much & 17 & 26.6 & 26 & 40.6 & 12 & 18.8 & 4 & 6.3 & 4 & 6.3 & 1 & 1.6 \\
\hline
\end{tabular}


Techniques used by WV Corn Producers to Control Cutworms

The second sub-division of cutworms under pest management consisted of 10 questions. Fifty-two (81.3\%) respondents agreed with the statement "I can identify cutworms" (see Table 11).

Forty-eight (75.0\%) respondents agreed with the statement "I am aware that cutworm thresholds are available.” Thirty-eight (60.3\%) respondents disagreed with the statement "I use thresholds for cutworms in corn” while 25 (39.7\%) respondents agreed. Thirty-four (55.7\%) respondents disagreed with the statement "Cutworms thresholds are easy to use” while 27 (44.2\%) respondents disagreed. Thirty-five (57.4\%) respondents disagreed with the statement "I have confidence in the cutworm thresholds" while 26 (42.6\%) agreed (see Table 11).

Thirty-seven (58.8\%) respondents disagreed with the statement "I have time to scout for cutworms.” Thirty-eight (59.4\%) respondents agreed with the statement "I apply insecticides for cutworm control” while 26 (40.6\%) disagreed. Fifty-nine (93.7\%) respondents disagreed with the statement "I use pheromone traps to forecast cutworm attack.” Fifty-seven (93.7\%) respondents disagreed with the statement "I use Degree-Day model to forecast cutworm attack.” Forty-nine (76.5\%) respondents agreed with the statement “I need information on cutworm forecasting” (see Table 11). 
Table 11

Techniques used by WV Corn Producers to Control Cutworms

\begin{tabular}{|c|c|c|c|c|c|c|c|c|c|c|c|c|}
\hline & \multicolumn{2}{|c|}{$\begin{array}{l}\text { Disagree } \\
\text { Strongly }\end{array}$} & \multicolumn{2}{|c|}{ Disagree } & \multicolumn{2}{|c|}{$\begin{array}{l}\text { Slightly } \\
\text { Disagree }\end{array}$} & \multicolumn{2}{|c|}{$\begin{array}{l}\text { Slightly } \\
\text { Agree }\end{array}$} & \multicolumn{2}{|c|}{ Agree } & \multirow{2}{*}{$\begin{array}{c}\text { Agree } \\
\mathrm{N}\end{array}$} & \multirow{2}{*}{$\begin{array}{c}\text { Strongly } \\
\%\end{array}$} \\
\hline & $\mathrm{N}$ & $\%$ & $\mathrm{~N}$ & $\%$ & $\mathrm{~N}$ & $\%$ & $\mathrm{~N}$ & $\%$ & $\mathrm{~N}$ & $\%$ & & \\
\hline I can identify cutworms & 2 & 3.1 & 7 & 10.9 & 3 & 4.7 & 8 & 12.5 & 38 & 59.4 & 6 & 9.4 \\
\hline $\begin{array}{l}\text { I am aware that cutworm thresholds } \\
\text { are available }\end{array}$ & 2 & 3.1 & 9 & 14.1 & 5 & 7.8 & 11 & 17.2 & 35 & 54.7 & 2 & 3.1 \\
\hline I use thresholds for cutworms in corn & 7 & 11.1 & 22 & 34.9 & 9 & 14.3 & 10 & 15.9 & 14 & 22.2 & 1 & 1.6 \\
\hline Cutworm thresholds are easy to use & 3 & 4.9 & 16 & 26.2 & 15 & 24.6 & 16 & 26.2 & 11 & 18.0 & 0 & .0 \\
\hline $\begin{array}{l}\text { I have confidence in the cutworm } \\
\text { thresholds }\end{array}$ & 3 & 4.9 & 17 & 27.9 & 15 & 24.6 & 16 & 26.2 & 10 & 16.4 & 0 & .0 \\
\hline I have time to scout for cutworms & 9 & 14.3 & 17 & 27.0 & 11 & 17.5 & 11 & 17.5 & 15 & 23.8 & 0 & .0 \\
\hline $\begin{array}{l}\text { I apply insecticides for cutworm } \\
\text { control }\end{array}$ & 3 & 4.7 & 21 & 32.8 & 2 & 3.1 & 8 & 12.5 & 28 & 43.8 & 2 & 3.1 \\
\hline $\begin{array}{l}\text { I use Pheromone traps to forecast } \\
\text { cutworm attack }\end{array}$ & 18 & 28.6 & 35 & 55.6 & 6 & 9.5 & 4 & 6.3 & 0 & .0 & 0 & .0 \\
\hline
\end{tabular}


Table 11 (Continued)

Techniques used by WV Corn Producers to Control Cutworms

\begin{tabular}{|c|c|c|c|c|c|c|c|c|c|c|c|c|}
\hline & \multicolumn{2}{|c|}{$\begin{array}{l}\text { Disagree } \\
\text { Strongly }\end{array}$} & \multicolumn{2}{|c|}{ Disagree } & \multicolumn{2}{|c|}{$\begin{array}{l}\text { Slightly } \\
\text { Disagree }\end{array}$} & \multicolumn{2}{|c|}{$\begin{array}{l}\text { Slightly } \\
\text { Agree }\end{array}$} & \multicolumn{2}{|c|}{ Agree } & \multirow{2}{*}{$\begin{array}{c}\text { Agree } \\
\mathrm{N}\end{array}$} & \multirow{2}{*}{$\begin{array}{c}\text { Strongly } \\
\%\end{array}$} \\
\hline & $\mathrm{N}$ & $\%$ & $\mathrm{~N}$ & $\%$ & $\mathrm{~N}$ & $\%$ & $\mathrm{~N}$ & $\%$ & $\mathrm{~N}$ & $\%$ & & \\
\hline $\begin{array}{l}\text { I use Degree-Day model to forecast } \\
\text { cutworm attack }\end{array}$ & 16 & 25.4 & 36 & 57.1 & 5 & 7.9 & 3 & 4.8 & 1 & 1.6 & 2 & 3.2 \\
\hline $\begin{array}{l}\text { I need information on cutworm } \\
\text { forecasting }\end{array}$ & 1 & 1.6 & 9 & 14.1 & 5 & 7.8 & 10 & 15.6 & 34 & 53.1 & 5 & 7.8 \\
\hline
\end{tabular}


Techniques used by WV Corn Producers to Control European Corn Borer

The third sub-division in the pest management group consisted of nine questions on European corn borer management. Forty-four (68.8\%) respondents disagreed with the statement "I can identify the egg masses of European corn borer" while 20 (31.3\%) of the respondents agreed. Forty-six (71.9\%) respondents agreed with the statement "I can identify the damage symptoms of corn borer” (see Table 12).

Thirty-six (56.3\%) respondents disagreed with the statement "I have time to scout for European corn borer” while 28 (43.7\%) disagreed. Forty-one (64.0\%) respondents disagreed with the statement "I apply insecticides for European corn borer control” while 23 (35.9\%) respondents agreed. Thirty-seven (58.7\%) respondents agreed with the statement "I plant corn early to reduce risk from European corn borer” while 26 (41.3\%) respondents disagreed. Fifty-two (81.3\%) respondents agreed with the statement "I plant Bt-corn to reduce risk from European corn borer” (see Table 12).

Sixty (93.8\%) respondents disagreed with the statement "I use pheromone traps to control European corn borer.” Thirty-nine (61.0\%) respondents disagreed with the statement "Trap crops including perimeter crops can effectively reduce pest incidence” while 25 (39.0\%) agreed. Fifty-two (82.6\%) respondents agreed with the statement "I need more information on European corn borer” (see Table 12). 
Table 12

Techniques used by WV Corn Producers to Control European Corn Borer

\begin{tabular}{|c|c|c|c|c|c|c|c|c|c|c|c|c|}
\hline & \multicolumn{2}{|c|}{$\begin{array}{l}\text { Disagree } \\
\text { Strongly }\end{array}$} & \multicolumn{2}{|c|}{ Disagree } & \multicolumn{2}{|c|}{$\begin{array}{l}\text { Slightly } \\
\text { Disagree }\end{array}$} & \multicolumn{2}{|c|}{$\begin{array}{l}\text { Slightly } \\
\text { Agree }\end{array}$} & \multicolumn{2}{|c|}{ Agree } & \multirow{2}{*}{$\begin{array}{r}\text { Agree } \\
\mathrm{N}\end{array}$} & \multirow{2}{*}{$\begin{array}{c}\text { Strongly } \\
\%\end{array}$} \\
\hline & $\mathrm{N}$ & $\%$ & $\mathrm{~N}$ & $\%$ & $\mathrm{~N}$ & $\%$ & $\mathrm{~N}$ & $\%$ & $\mathrm{~N}$ & $\%$ & & \\
\hline $\begin{array}{l}\text { I can identify the egg masses of } \\
\text { European corn borer }\end{array}$ & 9 & 14.1 & 25 & 39.1 & 10 & 15.6 & 12 & 18.8 & 7 & 10.9 & 1 & 1.6 \\
\hline $\begin{array}{l}\text { I can identify the damage symptoms } \\
\text { of corn borer }\end{array}$ & 4 & 6.3 & 9 & 14.1 & 5 & 7.8 & 15 & 23.4 & 28 & 43.8 & 3 & 4.7 \\
\hline $\begin{array}{l}\text { I have time to scout for European corn } \\
\text { borer }\end{array}$ & 8 & 12.5 & 19 & 29.7 & 9 & 14.1 & 15 & 23.4 & 12 & 18.8 & 1 & 1.6 \\
\hline $\begin{array}{l}\text { I apply insecticides for European corn } \\
\text { borer control }\end{array}$ & 5 & 7.8 & 29 & 45.3 & 7 & 10.9 & 8 & 12.5 & 13 & 20.3 & 2 & 3.1 \\
\hline $\begin{array}{l}\text { I plant corn early to reduce risk from } \\
\text { European corn borer }\end{array}$ & 5 & 7.9 & 14 & 22.2 & 7 & 11.1 & 16 & 25.4 & 15 & 23.8 & 6 & 9.5 \\
\hline $\begin{array}{l}\text { I plant Bt-corn to reduce risk from } \\
\text { European corn borer }\end{array}$ & 4 & 6.3 & 7 & 10.9 & 1 & 1.6 & 6 & 9.4 & 25 & 39.1 & 21 & 32.8 \\
\hline $\begin{array}{l}\text { I use pheromone traps to control } \\
\text { European corn borer }\end{array}$ & 15 & 23.4 & 41 & 64.1 & 4 & 6.3 & 3 & 4.7 & 1 & 1.6 & 0 & .0 \\
\hline
\end{tabular}


Table 12 (Continued)

Techniques used by WV Corn Producers to Control European Corn Borer

\begin{tabular}{|c|c|c|c|c|c|c|c|c|c|c|c|c|}
\hline & \multicolumn{2}{|c|}{$\begin{array}{l}\text { Disagree } \\
\text { Strongly }\end{array}$} & \multicolumn{2}{|c|}{ Disagree } & \multicolumn{2}{|c|}{$\begin{array}{l}\text { Slightly } \\
\text { Disagree }\end{array}$} & \multicolumn{2}{|c|}{$\begin{array}{l}\text { Slightly } \\
\text { Agree }\end{array}$} & \multicolumn{2}{|c|}{ Agree } & \multicolumn{2}{|c|}{ Agree Strongly } \\
\hline & $\mathrm{N}$ & $\%$ & $\mathrm{~N}$ & $\%$ & $\mathrm{~N}$ & $\%$ & $\mathrm{~N}$ & $\%$ & $\mathrm{~N}$ & $\%$ & $\mathrm{~N}$ & $\%$ \\
\hline $\begin{array}{l}\text { Trap crops including perimeter crops } \\
\text { can effectively reduce pest incidence }\end{array}$ & 3 & 4.7 & 22 & 34.4 & 14 & 21.9 & 14 & 21.9 & 9 & 14.1 & 2 & 3.1 \\
\hline $\begin{array}{l}\text { I need more information on European } \\
\text { corn borer management }\end{array}$ & 1 & 1.6 & 6 & 9.5 & 4 & 6.3 & 19 & 30.2 & 27 & 42.9 & 6 & 9.5 \\
\hline
\end{tabular}


Techniques used by WV Corn Producers to Control Armyworms

The fourth sub-division in the pest management group consisted of seven questions on armyworm management in corn. Forty-two (67.8\%) respondents agreed with the statement “I can identify armyworms” while 20 (32.2\%) of the respondents disagreed (see Table 13).

Thirty-five (54.8\%) respondents agreed with the statement "I am aware that armyworm thresholds are available” while 29 (45.4\%) disagreed. Forty-six (71.8\%) respondents disagreed with the statement "I use thresholds for armyworms in corn" while 18 (28.2\%) agreed. Forty (65.6\%) respondents disagreed with the statement “Armyworm thresholds are easy to use” while 21 (34.4\%) respondents agreed (see Table 13).

Forty-two (65.6\%) respondents disagreed with the statement "I have time to scout for armyworms” while 22 (34.4\%) respondents agreed. Thirty-six (57.1\%) respondents disagreed with the statement "I apply insecticides for armyworm control.” Forty-nine (76.6\%) respondents agreed with the statement "I need more information on armyworm management” (see Table 13). 
Table 13

Techniques used by WV Corn Producers to Control Armyworms

\begin{tabular}{|c|c|c|c|c|c|c|c|c|c|c|c|c|}
\hline & \multicolumn{2}{|c|}{$\begin{array}{l}\text { Disagree } \\
\text { Strongly }\end{array}$} & \multicolumn{2}{|c|}{ Disagree } & \multicolumn{2}{|c|}{$\begin{array}{l}\text { Slightly } \\
\text { Disagree }\end{array}$} & \multicolumn{2}{|c|}{$\begin{array}{l}\text { Slightly } \\
\text { Agree }\end{array}$} & \multicolumn{2}{|c|}{ Agree } & \multicolumn{2}{|c|}{$\begin{array}{l}\text { Agree } \\
\text { Strongly }\end{array}$} \\
\hline & $\mathrm{N}$ & $\%$ & $\mathrm{~N}$ & $\%$ & $\mathrm{~N}$ & $\%$ & $\mathrm{~N}$ & $\%$ & $\mathrm{~N}$ & $\%$ & $\mathrm{~N}$ & $\%$ \\
\hline I can identify armyworms & 4 & 6.5 & 10 & 16.1 & 6 & 9.7 & 8 & 12.9 & 28 & 45.2 & 6 & 9.7 \\
\hline $\begin{array}{l}\text { I am aware that armyworm thresholds } \\
\text { are available }\end{array}$ & 4 & 6.3 & 19 & 29.7 & 6 & 9.4 & 12 & 18.8 & 20 & 31.3 & 3 & 4.7 \\
\hline $\begin{array}{l}\text { I use thresholds for armyworms in } \\
\text { corn }\end{array}$ & 7 & 10.9 & 29 & 45.3 & 10 & 15.6 & 7 & 10.9 & 9 & 14.1 & 2 & 3.1 \\
\hline Armyworm thresholds are easy to use & 2 & 3.3 & 24 & 39.3 & 14 & 23.0 & 11 & 18.0 & 8 & 13.1 & 2 & 3.3 \\
\hline I have time to scout for armyworms & 7 & 10.9 & 24 & 37.5 & 11 & 17.2 & 12 & 18.8 & 9 & 14.1 & 1 & 1.6 \\
\hline $\begin{array}{l}\text { I apply insecticides for armyworm } \\
\text { control }\end{array}$ & 5 & 7.9 & 23 & 36.5 & 8 & 12.7 & 7 & 11.1 & 18 & 28.6 & 2 & 3.2 \\
\hline $\begin{array}{l}\text { I need more information on } \\
\text { armyworm management }\end{array}$ & 1 & 1.6 & 8 & 12.5 & 6 & 9.4 & 14 & 21.9 & 28 & 43.8 & 7 & 10.9 \\
\hline
\end{tabular}


Techniques used by WV Corn Producers to Control Wireworms

The fifth sub-division in the pest management group consisted of seven questions on wireworm management in corn. Thirty-six (56.3\%) respondents disagreed with the statement "I can identify wireworms" while 28 (43.7\%) of the respondents agreed (see Table 14).

Fifty-one (79.7\%) respondents disagreed with the statement "I have heard of monitoring wireworms using bait stations” while 13 (20.3\%) agreed. Sixty-two (96.8\%) respondents disagreed with the statement "I use bait stations to monitor wireworms in corn.” Thirty-four (54.9\%) respondents disagreed with the statement "Wireworm thresholds are too complicated" while 28 (45.1\%) respondents agreed (see Table 14).

Thirty-four (53.1\%) respondents agreed with the statement "I apply seed treatments for wireworm control.” Thirty-nine (60.9\%) respondents disagreed with the statement “I apply in-furrow insecticides to control wireworms” while 25 (39.1\%) agreed. Fifty-one (79.7\%) respondents agreed with the statement "I need more information on wireworm management” (see Table 14). 
Table 14

Techniques used by WV Corn Producers to Control Wireworms

\begin{tabular}{|c|c|c|c|c|c|c|c|c|c|c|c|c|}
\hline & \multicolumn{2}{|c|}{$\begin{array}{l}\text { Disagree } \\
\text { Strongly }\end{array}$} & \multicolumn{2}{|c|}{ Disagree } & \multicolumn{2}{|c|}{$\begin{array}{l}\text { Slightly } \\
\text { Disagree }\end{array}$} & \multicolumn{2}{|c|}{$\begin{array}{l}\text { Slightly } \\
\text { Agree }\end{array}$} & \multicolumn{2}{|c|}{ Agree } & \multicolumn{2}{|c|}{$\begin{array}{c}\text { Agree } \\
\text { Strongly }\end{array}$} \\
\hline & $\mathrm{N}$ & $\%$ & $\mathrm{~N}$ & $\%$ & $\mathrm{~N}$ & $\%$ & $\mathrm{~N}$ & $\%$ & $\mathrm{~N}$ & $\%$ & $\mathrm{~N}$ & $\%$ \\
\hline I can identify wireworms & 8 & 12.5 & 19 & 29.7 & 9 & 14.1 & 6 & 9.4 & 21 & 32.8 & 1 & 1.6 \\
\hline $\begin{array}{l}\text { I have heard of monitoring wireworms } \\
\text { using bait stations }\end{array}$ & 9 & 14.1 & 33 & 51.6 & 9 & 14.1 & 4 & 6.3 & 8 & 12.5 & 1 & 1.6 \\
\hline $\begin{array}{l}\text { I use bait stations to monitor } \\
\text { wireworms in corn }\end{array}$ & 15 & 23.4 & 40 & 62.5 & 7 & 10.9 & 0 & .0 & 2 & 3.1 & 0 & .0 \\
\hline $\begin{array}{l}\text { Wireworm thresholds are too } \\
\text { complicated }\end{array}$ & 4 & 6.5 & 16 & 25.8 & 14 & 22.6 & 14 & 22.6 & 10 & 16.1 & 4 & 6.5 \\
\hline $\begin{array}{l}\text { I apply seed treatments for wireworm } \\
\text { control }\end{array}$ & 6 & 9.4 & 15 & 23.4 & 9 & 14.1 & 3 & 4.7 & 26 & 40.6 & 5 & 7.8 \\
\hline $\begin{array}{l}\text { I apply in-furrow insecticides to } \\
\text { control wireworms }\end{array}$ & 6 & 9.4 & 28 & 43.8 & 5 & 7.8 & 8 & 12.5 & 12 & 18.8 & 5 & 7.8 \\
\hline $\begin{array}{l}\text { I need more information on wireworm } \\
\text { management }\end{array}$ & 1 & 1.6 & 5 & 7.8 & 7 & 10.9 & 12 & 18.8 & 32 & 50.0 & 7 & 10.9 \\
\hline
\end{tabular}


Techniques used by WV Corn Producers to Control White Grubs

The final sub-division in the pest management group consisted of 10 questions on White grub management in corn. Forty-two (67.8\%) respondents agreed with the statement "I can identify white grubs" while 20 (32.2\%) of the respondents agreed (see Table 15).

Fifty-four (85.7\%) respondents disagreed with the statement "I have heard of monitoring white grubs using baited wire traps.” Fifty-four (87.1\%) respondents disagreed with the statement "I use bait stations to monitor white grubs in corn.” Thirtyfour (53.9\%) respondents disagreed with the statement "White grub thresholds are too complicated” while 29 (46.1\%) respondents agreed (see Table 15).

Forty-six (71.9\%) respondents disagreed with the statement "I have heard about thresholds based on using a shovel to dig and count white grubs prior to planting corn.” Fifty-eight (90.6\%) respondents disagreed with the statement "I dig and count white grubs before planting corn.” Forty (62.5\%) respondents disagreed with the statement "I check for corn seed pests when I check my planting depth” while 17 (27.5\%) agreed (see Table 15).

Thirty-five (54.8\%) respondents agreed with the statement "I apply seed treatments to control white grubs” while 29 (45.2\%) disagreed. Forty-six (73.0\%) respondents disagreed with the statement "I apply in-furrow insecticides to control white grubs” while 17 (27.0\%) agreed. Fifty-two (81.2\%) respondents agreed with the statement "I need more information on white grub management” (see Table 15). 
Table 15

Techniques used by WV Corn Producers to Control White Grubs

\begin{tabular}{|c|c|c|c|c|c|c|c|c|c|c|c|c|}
\hline & \multicolumn{2}{|c|}{$\begin{array}{l}\text { Disagree } \\
\text { Strongly }\end{array}$} & \multicolumn{2}{|c|}{ Disagree } & \multicolumn{2}{|c|}{$\begin{array}{l}\text { Slightly } \\
\text { Disagree }\end{array}$} & \multicolumn{2}{|c|}{$\begin{array}{l}\text { Slightly } \\
\text { Agree }\end{array}$} & \multicolumn{2}{|c|}{ Agree } & \multirow{2}{*}{$\begin{array}{r}\text { Agree } \\
\mathrm{N}\end{array}$} & \multirow{2}{*}{$\begin{array}{c}\text { Strongly } \\
\%\end{array}$} \\
\hline & $\mathrm{N}$ & $\%$ & $\mathrm{~N}$ & $\%$ & $\mathrm{~N}$ & $\%$ & $\mathrm{~N}$ & $\%$ & $\mathrm{~N}$ & $\%$ & & \\
\hline I can identify white grubs & 3 & 4.8 & 11 & 17.7 & 6 & 9.7 & 7 & 11.3 & 29 & 46.8 & 6 & 9.7 \\
\hline $\begin{array}{l}\text { I have heard of monitoring white } \\
\text { grubs using baited wire traps }\end{array}$ & 10 & 15.9 & 37 & 58.7 & 7 & 11.1 & 4 & 6.3 & 5 & 7.9 & 0 & .0 \\
\hline $\begin{array}{l}\text { I use bait stations to monitor white } \\
\text { grubs in corn }\end{array}$ & 15 & 24.2 & 36 & 58.1 & 3 & 4.8 & 5 & 8.1 & 3 & 4.8 & 0 & .0 \\
\hline $\begin{array}{l}\text { White grub thresholds are too } \\
\text { complicated }\end{array}$ & 6 & 9.5 & 16 & 25.4 & 12 & 19.0 & 15 & 23.8 & 13 & 20.6 & 1 & 1.6 \\
\hline $\begin{array}{l}\text { I have heard about thresholds based } \\
\text { on using a shovel to dig and count } \\
\text { white grubs prior to planting corn }\end{array}$ & 10 & 15.6 & 30 & 46.9 & 6 & 9.4 & 11 & 17.2 & 7 & 10.9 & 0 & .0 \\
\hline $\begin{array}{l}\text { I dig and count white grubs before } \\
\text { planting corn }\end{array}$ & 18 & 28.1 & 35 & 54.7 & 5 & 7.8 & 3 & 4.7 & 2 & 3.1 & 1 & 1.6 \\
\hline $\begin{array}{l}\text { I check for corn seed pests when I } \\
\text { check my planting depth }\end{array}$ & 12 & 18.8 & 21 & 32.8 & 7 & 10.9 & 9 & 14.1 & 11 & 17.2 & 4 & 6.3 \\
\hline
\end{tabular}


Table 15 (Continued)

Techniques used by WV Corn Producers to Control White Grubs

\begin{tabular}{|c|c|c|c|c|c|c|c|c|c|c|c|c|}
\hline & \multicolumn{2}{|c|}{$\begin{array}{l}\text { Disagree } \\
\text { Strongly }\end{array}$} & \multicolumn{2}{|c|}{ Disagree } & \multicolumn{2}{|c|}{$\begin{array}{l}\text { Slightly } \\
\text { Disagree }\end{array}$} & \multicolumn{2}{|c|}{$\begin{array}{l}\text { Slightly } \\
\text { Agree }\end{array}$} & \multicolumn{2}{|c|}{ Agree } & \multirow{2}{*}{$\begin{array}{r}\text { Agree } \\
\mathrm{N}\end{array}$} & \multirow{2}{*}{$\begin{array}{c}\text { Strongly } \\
\%\end{array}$} \\
\hline & $\mathrm{N}$ & $\%$ & $\mathrm{~N}$ & $\%$ & $\mathrm{~N}$ & $\%$ & $\mathrm{~N}$ & $\%$ & $\mathrm{~N}$ & $\%$ & & \\
\hline $\begin{array}{l}\text { I apply seed treatments to control } \\
\text { white grubs }\end{array}$ & 8 & 12.5 & 17 & 26.6 & 4 & 6.3 & 9 & 14.1 & 22 & 34.4 & 4 & 6.3 \\
\hline $\begin{array}{l}\text { I apply in-furrow insecticides to } \\
\text { control white grubs }\end{array}$ & 10 & 15.9 & 31 & 49.2 & 5 & 7.9 & 4 & 6.3 & 10 & 15.9 & 3 & 4.8 \\
\hline $\begin{array}{l}\text { I need more information on white } \\
\text { grub management }\end{array}$ & 1 & 1.6 & 8 & 12.5 & 3 & 4.7 & 15 & 23.4 & 29 & 45.3 & 8 & 12.5 \\
\hline
\end{tabular}




\section{IPM Check List Responses by WV Corn Producers}

Part V of the survey questionnaire consisted of IPM Check List with 12 questions. The respondents were asked to indicate their opinion by putting check marks in the box that best corresponds to their response: yes or no.

The first question was "Do you follow crop rotation to reduce pest populations in your corn field?” to which 49 (76.6\%) respondents indicated their response as yes. Fortyeight (75.0\%) respondents indicated their response as yes to the question "Do you scout your corn field to familiarize yourself with the economic threshold of pests before taking a decision to spray chemicals?”(see Table 16).

Fifty-four (84.4\%) respondents indicated their response as no to the question "Do you estimate weed infestation using weed rating scale?” The fourth question was "Do you use cultural practices (timely cultivations) to control weeds?” to which 55 (85.9\%) respondents indicated their response as no (see Table 16).

Fifty (78.1\%) respondents indicated their response as yes to the question "Do you rotate your herbicide for weed control?” Thirty-eight (59.4\%) respondents indicated their response as yes to the question "Do you control weeds by spot application of herbicides?" while 26 (40.6\%) respondents indicated as no (see Table 16).

Fifty-three (82.8\%) respondents indicated their response as no to the question "Do you use Bt-Corn to control European corn borer?” Forty-seven (73.4\%) respondents indicated their response as no to the question "Do you calculate the pest defender ratio before taking up an insecticidal spray?” Fifty-seven (89.1\%) respondents indicated their 
response as yes to the question "Do you understand the toxicity levels of pesticides by reading the information on the label?” (see Table 16).

Table 16

IPM Check List Responses by WV Corn Producers

\begin{tabular}{|c|c|c|c|c|}
\hline & \multicolumn{2}{|c|}{ No } & \multicolumn{2}{|c|}{ Yes } \\
\hline & $\mathrm{N}$ & $\%$ & $\mathrm{~N}$ & $\%$ \\
\hline $\begin{array}{l}\text { Do you follow crop rotation to reduce pest } \\
\text { populations in your corn field? }\end{array}$ & 15 & 23.4 & 49 & 76.6 \\
\hline $\begin{array}{l}\text { Do you scout your corn field to familiarize } \\
\text { yourself with the economic threshold of pests } \\
\text { before taking a decision to spray chemicals? }\end{array}$ & 16 & 25.0 & 48 & 75.0 \\
\hline $\begin{array}{l}\text { Do you estimate weed infestation using weed } \\
\text { rating scale? }\end{array}$ & 54 & 84.4 & 10 & 15.6 \\
\hline $\begin{array}{l}\text { Do you use cultural practices (timely } \\
\text { cultivations) to control weeds? }\end{array}$ & 55 & 85.9 & 9 & 14.1 \\
\hline Do you rotate your herbicide for weed control? & 14 & 21.9 & 50 & 78.1 \\
\hline $\begin{array}{l}\text { Do you control weeds by spot application of } \\
\text { herbicides? }\end{array}$ & 26 & 40.6 & 38 & 59.4 \\
\hline $\begin{array}{l}\text { Do you use Bt-Corn to control European corn } \\
\text { borer }\end{array}$ & 11 & 17.2 & 53 & 82.8 \\
\hline $\begin{array}{l}\text { Do you calculate the pest defender ratio before } \\
\text { taking up an insecticidal spray? }\end{array}$ & 47 & 73.4 & 17 & 26.6 \\
\hline $\begin{array}{l}\text { Do you understand the toxicity levels of } \\
\text { pesticides by reading the information on the } \\
\text { label? }\end{array}$ & 7 & 10.9 & 57 & 89.1 \\
\hline $\begin{array}{l}\text { Do you use disease-resistant hybrid corn } \\
\text { varieties to control diseases? }\end{array}$ & 5 & 7.8 & 59 & 92.2 \\
\hline $\begin{array}{l}\text { Do you follow clean plow-down to control } \\
\text { diseases in corn? }\end{array}$ & 50 & 78.1 & 14 & 21.9 \\
\hline $\begin{array}{l}\text { Do you apply balanced fertilization to check } \\
\text { development of diseases in corn? }\end{array}$ & 27 & 42.2 & 37 & 57.8 \\
\hline
\end{tabular}


Fifty-nine (92.2\%) respondents indicated their response as yes to the question "Do you use disease-resistant hybrid corn varieties to control diseases?” Fifty (78.1\%) respondents indicated their response as no to the question "Do you follow clean plowdown to control diseases in corn?” Thirty-seven (57.8\%) respondents indicated their response yes to the question "Do you apply balanced fertilization to check development of diseases in corn?” while 27 (42.2\%) respondents responded no (see Table 16).

\section{Level of IPM Adoption by WV Corn Producers}

The score on Part V of the survey was totaled as used to categorize West Virginia corn producers into four categories, “No IPM” (score 1-3), “Low IPM” (score 4-6), “Medium Level IPM” (score 7-9), and “Bio-intensive IPM” (score 10-12).

Two (3.1\%) respondents were categorized in the "No IPM” group (see Table 17). Twenty-five (39.1\%) respondents were categorized in the "Low IPM” group (see Table 17). Thirty-one (48.4\%) corn producers were grouped in the "Medium Level IPM" category and six (9.4\%) respondents were grouped in the "Bio-intensive IPM” category (see Table 17).

Table 17

Level of IPM Adoption by WV Corn Producers

\begin{tabular}{lcc}
\hline & $\mathrm{N}$ & $\%$ \\
\hline No IPM & 2 & 3.1 \\
Low IPM & 25 & 39.1 \\
Medium IPM & 31 & 48.4 \\
Bio-Intensive IPM & 6 & 9.4 \\
\hline
\end{tabular}




\section{Educational Needs of West Virginia Corn Producers}

The educational needs of the West Virginia corn farmers were determined through this study. This section contained 10 questions from the questionnaire which were used to determine the educational needs of West Virginia corn farmers. The questions bearing numbers $26,27,34,35,36,52,61,68,75$ and 85 were used for this purpose.

Forty-seven (73.5\%) respondents agreed with the statement "I need more information on scouting for weeds in corn” while 17 (26.5\%) respondents disagreed. Forty (62.5\%) respondents disagreed with the statement "I need more information on weed management by cultivation” while 24 (37.5\%) agreed. Forty-nine (76.5\%) respondents agreed with the statement "I need more information on scouting for diseases in corn” (see Table 18).

Fifty-five (87.2\%) respondents agreed with the statement “I need more information on seed treatment to control diseases” while eight (12.6\%) respondents disagreed. Fifty-five (87.3\%) respondents agreed with the statement "I need more information on disease management of corn” (see Table 18).

Forty-nine (76.5\%) respondents agreed with the statement "I need information on cutworm forecasting” while 15 (23.5\%) disagreed. Fifty-two (82.6\%) respondents agreed with the statement "I need more information on European corn borer management." Forty-nine (76.6\%) respondents agreed with the statement "I need more information on armyworm management.” Fifty-one (79.7\%) respondents agreed with the statement "I need more information on wireworm management” while 13 (20.3\%) disagreed. Fifty- 
two (81.2\%) respondents agreed with the statement "I need more information on white grub management” (see Table 18).

Table 18

Educational Needs of WV Corn Producers

\begin{tabular}{|c|c|c|c|c|}
\hline & \multicolumn{2}{|c|}{ Disagree } & \multicolumn{2}{|c|}{ Agree } \\
\hline & $\mathrm{N}$ & $\%$ & $\mathrm{~N}$ & $\%$ \\
\hline $\begin{array}{l}\text { I need more information on scouting } \\
\text { for weeds in corn }\end{array}$ & 17 & 26.6 & 47 & 73.5 \\
\hline $\begin{array}{l}\text { I need more information on weed } \\
\text { management by cultivation }\end{array}$ & 40 & 62.5 & 24 & 37.5 \\
\hline $\begin{array}{l}\text { I need more information on scouting } \\
\text { for diseases in corn }\end{array}$ & 15 & 23.5 & 49 & 76.5 \\
\hline $\begin{array}{l}\text { I need more information on seed } \\
\text { treatment to control diseases }\end{array}$ & 8 & 12.6 & 55 & 87.2 \\
\hline $\begin{array}{l}\text { I need more information on disease } \\
\text { management of corn }\end{array}$ & 8 & 12.6 & 55 & 87.3 \\
\hline $\begin{array}{l}\text { I need information on cutworm } \\
\text { forecasting }\end{array}$ & 15 & 23.5 & 49 & 76.5 \\
\hline $\begin{array}{l}\text { I need more information on European } \\
\text { corn borer management }\end{array}$ & 11 & 17.4 & 52 & 82.6 \\
\hline $\begin{array}{l}\text { I need more information on armyworm } \\
\text { management }\end{array}$ & 15 & 23.5 & 49 & 76.6 \\
\hline $\begin{array}{l}\text { I need more information on wireworm } \\
\text { management }\end{array}$ & 13 & 20.3 & 51 & 79.7 \\
\hline $\begin{array}{l}\text { I need more information on white grub } \\
\text { management }\end{array}$ & 12 & 18.8 & 52 & 81.2 \\
\hline
\end{tabular}




\section{CHAPTER V}

Summary, Conclusions and Recommendations

Purpose of the Study

The purpose of this research study was to provide information to the West Virginia Extension Service that may be useful in designing and developing educational programs on integrated pest management. To accomplish this, a purposeful sample of 100 corn producers were surveyed for their knowledge on integrated pest management practices, the barriers in adoption of integrated pest management and the educational needs of West Virginia corn producers on integrated pest management. The aggregate response rate from this sample was $64 \%$.

\section{Objectives of the Study}

The objectives of the study were:

1. To determine the knowledge of the West Virginia corn producers on integrated pest management practices.

2. To determine the level of adoption of integrated pest management practices by corn growers in West Virginia.

3. To determine the barriers in adoption of integrated pest management by West Virginia corn growers.

4. To determine the educational needs of the West Virginia corn growers on integrated pest management in corn. 


\section{Summary}

The purpose of this study was to provide information to the WVU Extension personnel and researchers that may be useful in designing and developing educational programs on integrated pest management practices in corn.

Data were collected via surveys mailed to 20 corn producers of the top five corn producing counties in West Virginia. The corn producers of each county were selected at random by the respective county Extension Agents. Sixty-four surveys were returned and data from these surveys were pooled and analyzed for this study.

The survey consisted of six parts. Part I of the survey inquired about general aspects of pesticides and their impact on environment. Part II, III and IV of the survey inquired about the current pest management adoption trends and barriers in adoption of IPM in weeds, insect pests and diseases respectively and their educational needs on IPM. Part V was designed to document level of adoption of IPM practices by corn growers in West Virginia. Part VI of the survey documents the demographic information of the participants. A cover letter signed by the researcher and the committee chairman, explaining the purpose of the study and gave directions for completing the questionnaire was also included. A self-addressed stamped envelope was included to help encourage the return of the instrument.

Characteristics of the 64 respondents were as follows. Twenty-eight (43.7\%) of the respondents had acreage below 100 acres. Nineteen respondents had acreage between 100 and 250 acres while 17 (26.6\%) of the respondents had above 250 acres. Seventeen (26.6\%) of the participants are below the age of 50 years while 47 (73.4\%) are above 50 years. Thirty respondents were high school graduates while 20 (31.3\%) had a four-year 
degree and above. Forty-three percent of the responding corn producers have not attended IPM training.

When asked about general perception of pesticide usage and alternative methods, $100 \%$ of the respondents indicated that agricultural chemicals are vital for good crop yields. Thirty-eight percent of the respondents indicated agricultural chemicals cause air pollution while $51 \%$ of the respondents indicated that agricultural chemicals cause water pollution. More than ninety-five percent (98.4\%) of the respondents felt that repeated use of herbicides with the same mode of action lead to resistance biotypes of weeds while 96.6\% respondents felt that repeated use of insecticides with the same mode of action lead to resistance in biotypes of insects. More than $90 \%$ of the respondents indicated crop rotation is a good method to control weed and insect pest populations. More than 70 percent $(71.9 \%)$ of the respondents agreed that there are other methods than chemicals to control pests in corn.

When asked about weed management, $75 \%$ of the respondents indicated that they are confident in weed identification skills and $79.4 \%$ of the respondents indicated they personally scout for weeds. Ninety-seven percent of the respondents relied on herbicides than cultivation to control weeds in corn. Seventy-four percent of the respondents needed more information on scouting for weeds while $38 \%$ of the respondents needed more information on weed management by cultivation.

Fifty-six percent of the respondents scouted personally for diseases but $69 \%$ of the respondents were not confident in their disease identification skills. More than $90 \%$ of the respondents select disease resistant corn varieties to control diseases in corn. Eighty- 
seven percent of the respondents needed more information on seed treatment and disease management in corn.

When asked about pest management, 81.3\%, 71.9\%, 67.8\%, 43.8\%, and 67.8\% of the respondents were confident of identifying cutworms, European corn borer, armyworms, wireworms and white grubs respectively. Less than $10 \%$ of the respondents used pheromone traps or Degree-Day model to forecast cutworm attack. Eighty-one percent of the respondents planted Bt-Corn to reduce risk from European corn borer. Fifty-nine percent of the respondents planted corn early to reduce risk of European corn borer while 36\% apply insecticides to control European corn borer. Twenty-eight percent of the respondents used thresholds for armyworm control and $43 \%$ of the respondents applied insecticides for armyworm control. Ninety-seven did not use bait stations for monitoring wireworms. Fifty-three percent of the respondents applied seed treatment for wireworm control while $39 \%$ of the respondents applied in-furrow insecticides to control wireworms. More than $85 \%$ of the respondents had not heard of monitoring white grubs using baited wire traps and never used the technique. Ninety percent of the respondents did not dig and count white grubs before planting corn. Seventy-three percent of the respondents did not apply in-furrow insecticides to control white grubs in corn.

The scores on part V were used to categorize the respondents into various levels of adoption of integrated pest management. Twenty-five (39.1\%) respondents were categorized in the "Low IPM" group. Thirty-one (48.4\%) were grouped in the "Medium Level IPM” category and six (9.4\%) respondents were grouped in the "Bio-intensive IPM” category. 
More than 75\% of the responding WV corn producers needed more information on various management practices in corn.

\section{Conclusions}

Because a purposeful sample was used in the data collection procedure in the study, it was not possible for the researcher to generalize the results of this study to include corn producers outside of the 64 respondents. Based on the data obtained through the survey of West Virginia corn producers, the following conclusions were reached:

1. Respondents needed more information on weed rating scale and cultivation techniques to control weeds in corn.

2. Respondents needed more information on scouting for weeds in corn and preparation of paper and computer maps of hotspots in cornfields.

3. Respondents needed more information on scouting for diseases in corn and seed treatment techniques to control diseases.

4. Respondents needed information on techniques like clean plow-down and balanced fertilization to check development of diseases in corn.

5. Respondents needed information on cutworm threshold levels and cutworm attack forecasting techniques like pheromone traps and degree-day models.

6. Respondents needed information on pheromone traps and other techniques like trap cropping including perimeter crops to reduce pest incidence of European corn borer. 
7. Respondents needed more information on armyworm threshold levels and armyworm management.

8. Respondents needed more information on use of bait stations to monitor wireworms in corn and in-furrow application of insecticides to control wireworms when needed.

9. Respondents needed information on use of bait stations to monitor white grubs in corn and in-furrow application of insecticides, if needed.

10. Respondents need information on calculation of pest-defender ratio before taking up an insecticidal spray, when needed.

\section{Discussion}

The findings presented as a result of this study were not vastly different than those identified by Malone et al., (2004) in their study to determine IPM adoption strategies for corn, soybeans, and small grain in the coastal plains of Virginia.

The IPM practices often used by the West Virginia corn producers:

1. Scouting for weeds, insects and diseases in their corn fields.

2. Use of scouting to manage pests in corn.

3. Use of herbicides with different mode of action to avoid development of resistance.

4. Practicing crop rotation to minimize pest populations. 
5. Early planting of corn to reduce the risk of European corn borer.

The IPM practices often not used by the West Virginia corn producers:

1. Having Extension Agents scout for pests in their corn fields.

2. Having independent crop consultant scout for pests in their corn fields.

3. Use of cultivation to control weeds in their corn fields.

4. Mapping hot spots for weeds in their corn fields.

5. Use of bait stations to monitor soil borne pests.

6. Use of pheromone traps to forecast European corn borer.

\section{Recommendations}

Based on the results obtained from the study, the following recommendations are offered:

1. Results of this study should be made available to West Virginia County Extension Agents and West Virginia University researchers and Extension Specialists.

2. It should be determined if the educational needs of the corn producers of WV match the needs of purposeful sample of the five counties.

3. Best IPM practices should be developed for corn production in West Virginia and made available to corn producers.

4. Educators should strive to involve 100 percent of the farming community in their IPM training programs. 
5. Educational workshops for West Virginia corn producers should emphasize the following topics:

a. Weed rating scale and cultivation techniques to control weeds in corn;

b. Scouting for weeds in corn and preparation of paper and computer maps of hotspots in cornfields;

c. Scouting for diseases in corn and seed treatment techniques to control diseases;

d. Clean plow-down techniques and balanced fertilization to check development of diseases in corn;

e. Cutworm threshold levels and cutworm attack forecasting techniques like pheromone traps and degree-day models;

f. Pheromone traps and other techniques like trap cropping including perimeter crops to reduce pest incidence of European corn borer;

g. Armyworm threshold levels and armyworm management;

h. Use of bait stations to monitor wireworms in corn and in-furrow application of insecticides to control wireworms when needed;

i. Use of bait stations to monitor white grubs in corn and in-furrow application of insecticides, if needed; and

j. Calculation of pest-defender ratio before taking up an insecticidal spray, when needed. 


\section{REFERENCES}

Alexandre, V., Nehring, R., Cornejo, J. F., \& Grube, A. (2008). Impact of GMO crop adoption on quality-adjusted pesticide use in corn and soybeans: A full picture. Paper prepared for presentation at the American Agricultural Economics Association Annual Meeting, Orlando, FL, July 27-29, 2008.

Alston, D. G., \& Reading, M. E. (1998). Factors influencing adoption and educational outreach of integrated pest management. Journal of Extension, 36(3). Retrieved October 25, 2008 from http://www.joe.org/joe/1998june/a3.php.

Ary, D., Jacobs, C. L., \& Razavieh, A. (1972). Introduction to research in education. New York: Holt, Rinehart and Winston, Inc.

Benbrook, C. M., Groth III, E., Halloran, J. M., Hansen, M. K., \& Marquardt, S. (1996). Pest management at the crossroads. New York: Consumer Union of United States Inc., New York.

Bloom, S. C., \& Degler, S. E.(1969). Pesticides and pollution. Washington: BNA’s Environmental Management Series.

Clark, J., \& Yamagunchi, I. (2002). Agrochemical resistance. Washington: American Chemical Society, Washington, DC.

Dent, D. (2001). The history of pest management. (2001). Retrieved November 8, 2008, from http://http://www.safe2use.com/ca-ipm/01-04-27.htm.

Dillman, A. (2000). Mail and internet surveys: The tailored design method (2 ${ }^{\text {nd }}$ edition). New York: John Wiley \& Sons.

Drost, D., Long, G., Wilson, D., Miller, B., \& Campbell, W. (1996). Barriers to adopting sustainable agricultural practices. Journal of Extension, 34(6). Retrieved November 2, 2008 from http://www.joe.org/joe/1996december/a1.php.

Food and Agricultural organization (FAO). (n. d.). Retrieved February 10, 2009 from http://faostat.fao.org/site/567/DesktopDefault.aspx?PageID=567\#ancor.

Food and Agricultural organization (FAO). (n. d.). Retrieved February 10, 2009 from http://www.fao.org/ag/AGP/AGPP/IPM/Default.htm.

Kotler, P. \& Armstrong, G. (1991). Principles of marketing. NJ: Prentice-Hall, Inc.

Malone, S. D., Herbert, Jr., A., and Pheasant, S. (2004). Determining adoption of Integrated pest management practices by grains farmers in Virginia. Retrieved November 15, 2008 from http://www.dcr.virginia.gov/soil_\&_water/documents/ipmresults.pdf. 
Pedigo, L. (2002) Entomology and pest management (4th edition). Upper Saddle River, New Jersey: Prentice Hall.

Robinson, J. P., Shaver, P. R., \& Wrightsman, L. S. (1991). Criteria for scale selection and evaluation. In J. P. Robinson, Shaver, \& L. S. Wrightsman (Eds.). Measures of personality and social psychological attitudes (pp. 1-16) New York: Academic Press.

Seevers, B., Graham, D., Gamon, J., \& Conklin, N. (1995). Education through cooperative extension. Albany, NY: Delmar Publishers.

Simmons, J., \& McCall, G. (1985). Social research: The craft of finding out. New York: Macmillan Publishing Company.

Steffey, K., \& Gary, M. (2008). An IPM check list for commercial corn and soybean production. The Bulletin, No 1Article 2/March 21, 2008. Retrieved October 15, 2008 from http://ipm.uiuc.edu/bulletin/article.php?id=877.

Trede, L. D., \& Whittaker, S. (1998). Beginning farmer education in Iowa: Implications to extension. Journal of Extension, 36(5). Retrieved December 2, 2008 from http://www.joe.org/joe/1998october/a3.php.

United States Department of Agriculture (USDA). (n.d.). Retrieved September 27, 2008 from http://www.usda.gov/.

United States Department of Agriculture (USDA). (1997). Retrieved November 4, 2008 from http://www.ers.usda.gov/publications/mp1542/MP1542c.PDF.

United States Department of Agriculture (USDA). (2009). Retrieved November 5, 2008 from http://www.nass.usda.gov/QuickStats/PullData_US_CNTY.jsp.

United States Environmental Protection Agency (U.S.EPA). (n. d.). Retrieved September 27, 2008 from http://www.epa.gov/NHEERL/research/human_health.html.

United States Environmental Protection Agency (U.S.EPA). (2008). Retrieved November 2, 2008 from http://www.epa.gov/opp00001/factsheets/ipm.htm. 
APPENDICES 


\section{APPENDIX A}

Email correspondence with the County Extension Agents 
March 1, 2008

\section{Dear County Extension Agent:}

I am in the process of conducting research on "Adoption Levels of Integrated Pest Management among Corn Producers in West Virginia.” The results of this study will be used to prepare a thesis to partially fulfill the requirements for a Master of Science Degree in Agricultural and Extension Education.

Currently, I am working under the guidance of Dr. Stacy A. Gartin, professor and chair, Agricultural and Extension Education at WVU. Other members on my committee are Dr. Harry N. Boone Jr., Dr. Deborah A. Boone and Dr. Rakesh S. Chandran.

In order to complete my research study and reach my target population, we need your help. The questionnaire will be administered to a sample of 20 corn producers from the top five corn producing counties in West Virginia. Your county is one of the five top corn producing counties in West Virginia. Please select 20 corn producers in your county at random to participate in the study. Kindly provide the mailing addresses and contact numbers to administer the questionnaire. Results will be made available to you and your colleagues upon completion of the study.

Thank you in advance for your help. Your assistance is of utmost importance and we sincerely appreciate your time and effort.

Sincerely,

Hari Vommi

Graduate Student

Stacy Gartin

Professor, Agriculture Education 
APPENDIX B

Questionnaire 


\title{
ADOPTION LEVELS OF INTEGRATED PEST MANAGEMENT AMONG CORN PRODUCERS IN WEST VIRGINIA
}

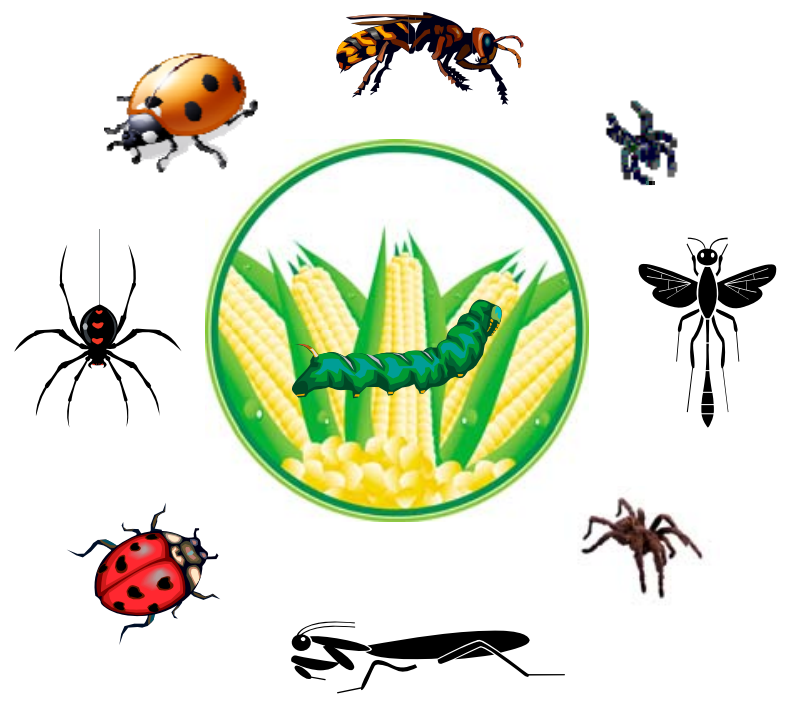

\author{
Hari Krishna Vommi \\ Graduate Student \\ Agricultural and Extension Education \\ Davis College of Agriculture, Forestry, and Consumer Sciences \\ West Virginia University \\ Morgantown, WV 26506
}




\section{Adoption Levels of Integrated Pest Management}

\section{Among Corn Producers in West Virginia}

Instructions: Using the following Likert Scale, rate your opinion on each of the following questions. Please indicate your opinion by circling the letters in the box that best correspond to your response: DS - Disagree Strongly, D - Disagree, SD - Slightly Disagree, SA - Slightly Agree, A - Agree, and AS - Agree Strongly.

Example: Read the following statement. Assume that you Agree Strongly with the Statement circle AS in the box indicated below.

\begin{tabular}{|c|c|c|c|c|c|c|}
\hline Statement & 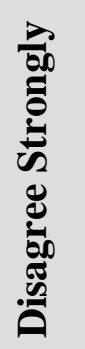 & 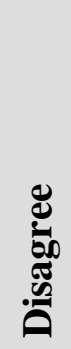 & 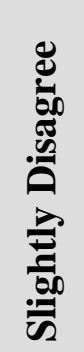 & 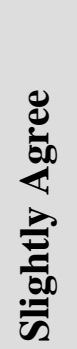 & 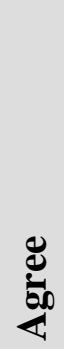 & 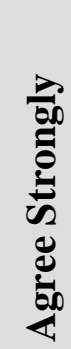 \\
\hline $\begin{array}{l}\text { Agriculture sector is the major contributor to the } \\
\text { economy of United States of America. }\end{array}$ & DS & D & SD & SA & A & \\
\hline
\end{tabular}

\begin{tabular}{|c|c|c|c|c|c|c|}
\hline Statement & 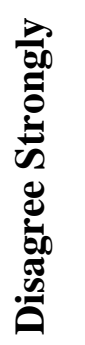 & 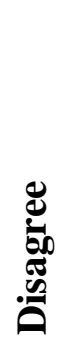 & 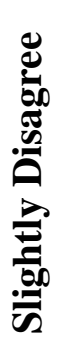 & 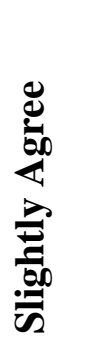 & 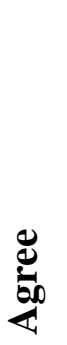 & 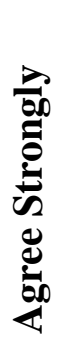 \\
\hline \multicolumn{7}{|l|}{ Part I : GENERAL } \\
\hline $\begin{array}{l}\text { 1. Agriculture chemicals are vital for good } \\
\text { crop yields. }\end{array}$ & DS & D & SD & SA & A & AS \\
\hline $\begin{array}{l}\text { 2. Chemicals used in agriculture cause air } \\
\text { pollution. }\end{array}$ & DS & D & SD & SA & A & AS \\
\hline $\begin{array}{l}\text { 3. Chemicals used in agriculture cause water } \\
\text { pollution. }\end{array}$ & DS & D & SD & SA & A & AS \\
\hline
\end{tabular}




\begin{tabular}{|c|c|c|c|c|c|c|}
\hline Statement & 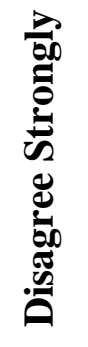 & 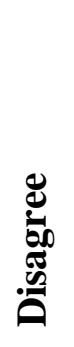 & 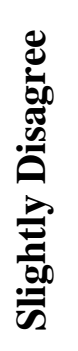 & 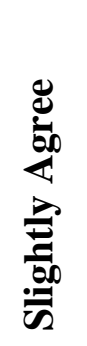 & 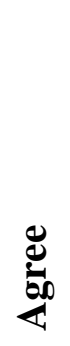 & 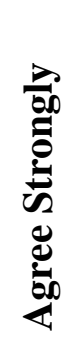 \\
\hline $\begin{array}{l}\text { 4. Repeated use of herbicides with the same } \\
\text { mode of action may lead to resistance } \\
\text { biotypes of weeds. }\end{array}$ & DS & D & SD & SA & A & AS \\
\hline $\begin{array}{l}\text { 5. Crop rotation is good method to control } \\
\text { weed population. }\end{array}$ & DS & D & SD & SA & A & AS \\
\hline $\begin{array}{l}\text { 6. All insects seen on the crop cause } \\
\text { to crops. }\end{array}$ & DS & D & SD & SA & $\mathbf{A}$ & AS \\
\hline $\begin{array}{l}\text { 7. Repeated use of insecticides with the same } \\
\text { mode of action may lead to resistance in } \\
\text { biotypes of insects. }\end{array}$ & DS & D & SD & SA & A & AS \\
\hline $\begin{array}{l}\text { 8. Crop rotation is good method of control } \\
\text { insect pest populations. }\end{array}$ & DS & D & SD & SA & A & AS \\
\hline $\begin{array}{l}\text { 9. Exposure to pesticides results in serious } \\
\text { health problems. }\end{array}$ & DS & D & SD & SA & A & AS \\
\hline $\begin{array}{l}\text { 10. Use of Bt-Corn reduces the number of } \\
\text { sprayings against insect pests. }\end{array}$ & DS & D & SD & SA & A & AS \\
\hline $\begin{array}{l}\text { 11. Protection gear should be worn while } \\
\text { spraying pesticides. }\end{array}$ & DS & D & SD & SA & A & AS \\
\hline $\begin{array}{l}\text { 12. No pesticide should be applied within } 30 \\
\text { meters of well used for domestic purpose. }\end{array}$ & DS & D & SD & SA & A & AS \\
\hline $\begin{array}{l}\text { 13. The speed of spray vehicle should not } \\
\text { exceed } 10 \text { miles/hour while spraying. }\end{array}$ & DS & D & SD & SA & A & AS \\
\hline $\begin{array}{l}\text { 14. Crop rotation reduces the crop damage due } \\
\text { to diseases. }\end{array}$ & DS & D & SD & SA & A & AS \\
\hline $\begin{array}{l}\text { 15. Seed treatment with fungicide helps in } \\
\text { reducing the soil borne diseases in corn. }\end{array}$ & DS & D & SD & SA & A & AS \\
\hline $\begin{array}{l}\text { 16. There are other methods than chemicals to } \\
\text { control pests in corn. }\end{array}$ & DS & D & SD & SA & A & AS \\
\hline
\end{tabular}




\begin{tabular}{|c|c|c|c|c|c|c|}
\hline Statement & 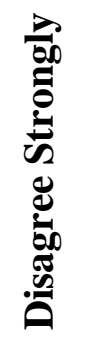 & 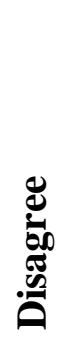 & 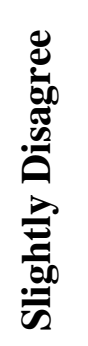 & 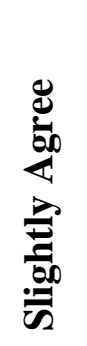 & 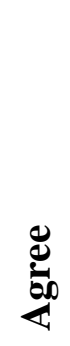 & 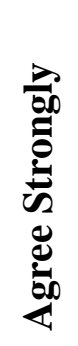 \\
\hline \multicolumn{7}{|l|}{ Part II : WEED MANAGEMENT } \\
\hline $\begin{array}{l}\text { 17. I am confident in my weed identification } \\
\text { skills. }\end{array}$ & DS & $\mathbf{D}$ & SD & SA & A & AS \\
\hline 18. I have adequate time to scout for weeds. & DS & $\mathbf{D}$ & SD & SA & A & AS \\
\hline 19. I personally scout for weeds in my corn. & DS & $\mathbf{D}$ & SD & SA & A & AS \\
\hline 20. I cultivate to control weeds in corn. & DS & D & SD & SA & A & AS \\
\hline $\begin{array}{l}\text { 21. Cultivation adequately controls weeds in } \\
\text { my corn. }\end{array}$ & DS & D & SD & SA & A & AS \\
\hline $\begin{array}{l}\text { 22. Corn gets too tall for me to cultivate } \\
\text { effectively. }\end{array}$ & DS & D & SD & SA & A & AS \\
\hline $\begin{array}{l}\text { 23. Scouting for weeds requires too much } \\
\text { walking. }\end{array}$ & DS & $\mathbf{D}$ & SD & SA & A & AS \\
\hline $\begin{array}{l}\text { 24. I make paper or computer maps of weed } \\
\text { hotspots in my cornfields. }\end{array}$ & DS & D & SD & SA & A & AS \\
\hline $\begin{array}{l}\text { 25. I rely more on herbicides than cultivation } \\
\text { to control weeds in corn. }\end{array}$ & DS & D & SD & SA & A & AS \\
\hline $\begin{array}{l}\text { 26. I need more information on Scouting for } \\
\text { weeds in corn. }\end{array}$ & DS & D & SD & SA & A & AS \\
\hline $\begin{array}{l}\text { 27. I need more information on weed } \\
\text { management by cultivation. }\end{array}$ & DS & D & SD & SA & A & AS \\
\hline \multicolumn{7}{|l|}{ Part III : DISEASE MANAGEMENT } \\
\hline $\begin{array}{l}\text { 28. I am confident in my disease identification } \\
\text { skills. }\end{array}$ & DS & D & SD & SA & A & AS \\
\hline 29. I have adequate time to scout for diseases. & DS & $\mathbf{D}$ & SD & SA & A & AS \\
\hline 30. I scout for diseases in my corn. & DS & D & SD & SA & A & AS \\
\hline 31. I select corn seed treated with fungicides. & DS & $\mathbf{D}$ & SD & SA & A & AS \\
\hline 32. I select disease-resistant corn varieties. & DS & D & SD & SA & $\mathbf{A}$ & AS \\
\hline
\end{tabular}




\begin{tabular}{|c|c|c|c|c|c|c|}
\hline Statement & 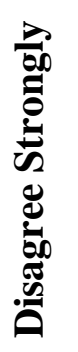 & 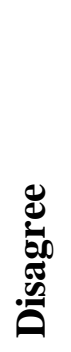 & 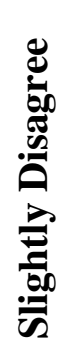 & 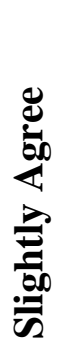 & 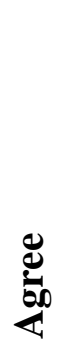 & 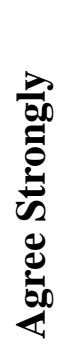 \\
\hline $\begin{array}{l}\text { 33. Scouting for diseases helps me decide if I need } \\
\text { to rotate future crops to avoid diseases. }\end{array}$ & DS & $\mathbf{D}$ & SD & SA & A & AS \\
\hline $\begin{array}{l}\text { 34. I need more information on scouting for } \\
\text { diseases in corn. }\end{array}$ & DS & $\mathbf{D}$ & SD & SA & A & AS \\
\hline $\begin{array}{l}\text { 35. I need more information on seed treatment to } \\
\text { control diseases. }\end{array}$ & DS & $\mathbf{D}$ & SD & SA & A & AS \\
\hline $\begin{array}{l}\text { 36. I need more information on disease } \\
\text { management of corn. }\end{array}$ & DS & $\mathbf{D}$ & SD & SA & A & AS \\
\hline \multicolumn{7}{|l|}{ Part IV : PEST MANAGEMENT } \\
\hline \multicolumn{7}{|l|}{ Scouting for Insects } \\
\hline 37. I personally scout my corn for insects. & DS & $\mathbf{D}$ & SD & SA & A & AS \\
\hline 38. An Extension Agent scouts my corn for insects. & DS & $\mathbf{D}$ & SD & SA & A & AS \\
\hline $\begin{array}{l}\text { 39. An independent crop consultant scouts my corn } \\
\text { for insects. }\end{array}$ & DS & $\mathbf{D}$ & SD & SA & A & AS \\
\hline 40. Scouting for insects requires too much time. & DS & $\mathbf{D}$ & SD & SA & A & AS \\
\hline 41. Scouting for insects requires too much walking. & DS & $\mathbf{D}$ & SD & SA & A & AS \\
\hline 42. Scouting for insects costs too much. & DS & D & SD & SA & A & AS \\
\hline \multicolumn{7}{|l|}{ Cutworms } \\
\hline 43. I can identify cutworms. & DS & $\mathbf{D}$ & SD & SA & A & AS \\
\hline $\begin{array}{l}\text { 44. I am aware that cutworm thresholds are } \\
\text { available. }\end{array}$ & DS & $\mathbf{D}$ & SD & SA & A & AS \\
\hline 45. I use thresholds for cutworms in corn. & DS & $\mathbf{D}$ & SD & SA & A & AS \\
\hline 46. Cutworm thresholds are easy to use. & DS & D & SD & SA & A & AS \\
\hline 47. I have confidence in the cutworm thresholds. & DS & D & SD & SA & A & AS \\
\hline 48. I have time to scout for cutworms. & DS & D & SD & SA & A & AS \\
\hline
\end{tabular}




\begin{tabular}{|c|c|c|c|c|c|c|}
\hline Statement & 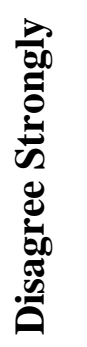 & 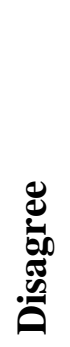 & 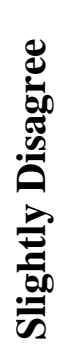 & 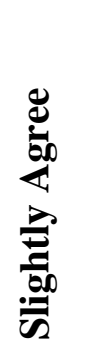 & 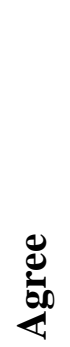 & 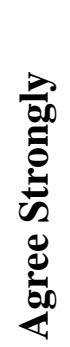 \\
\hline 49. I apply insecticides for cutworm control. & DS & $\mathbf{D}$ & SD & SA & A & AS \\
\hline $\begin{array}{l}\text { 50. I use Pheromone traps to forecast cutworm } \\
\text { attack. }\end{array}$ & DS & D & SD & SA & A & AS \\
\hline $\begin{array}{l}\text { 51. I use Degree-Day model to forecast } \\
\text { cutworm attack. }\end{array}$ & DS & D & SD & SA & A & AS \\
\hline 52. I need information on cutworm forecasting. & DS & $\mathbf{D}$ & SD & SA & $\mathbf{A}$ & AS \\
\hline \multicolumn{7}{|l|}{ European Corn Borer } \\
\hline $\begin{array}{l}\text { 53. I can identify the egg masses of European } \\
\text { corn borer. }\end{array}$ & DS & D & SD & SA & A & AS \\
\hline $\begin{array}{l}\text { 54. I can identify the damage symptoms of } \\
\text { European corn borer. }\end{array}$ & DS & D & SD & SA & A & AS \\
\hline $\begin{array}{l}\text { 55. I have time to scout for European corn } \\
\text { borer. }\end{array}$ & DS & D & SD & SA & A & AS \\
\hline $\begin{array}{l}\text { 56. I apply insecticides for European corn } \\
\text { borer control. }\end{array}$ & DS & D & SD & SA & A & AS \\
\hline $\begin{array}{l}\text { 57. I plant corn early to reduce risk from } \\
\text { European corn borer. }\end{array}$ & DS & D & SD & SA & A & AS \\
\hline $\begin{array}{l}\text { 58. I plant Bt-corn to reduce risk from } \\
\text { European corn borer. }\end{array}$ & DS & D & SD & SA & A & AS \\
\hline $\begin{array}{l}\text { 59. I use pheromone traps to control European } \\
\text { corn borer. }\end{array}$ & DS & D & SD & SA & A & AS \\
\hline $\begin{array}{l}\text { 60. Trap crops including perimeter crops can } \\
\text { effectively reduce pest incidence. }\end{array}$ & DS & D & SD & SA & A & AS \\
\hline $\begin{array}{l}\text { 61. I need more information on European corn } \\
\text { borer management. }\end{array}$ & DS & D & SD & SA & A & AS \\
\hline \multicolumn{7}{|l|}{ Armyworms } \\
\hline 62. I can identify armyworms. & DS & D & SD & SA & A & AS \\
\hline
\end{tabular}




\begin{tabular}{|c|c|c|c|c|c|c|}
\hline Statement & 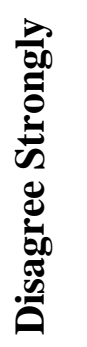 & 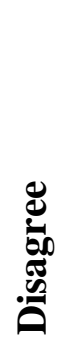 & 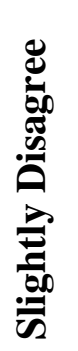 & 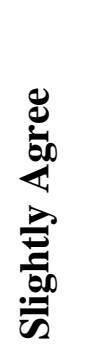 & 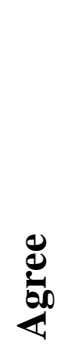 & 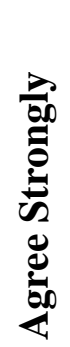 \\
\hline $\begin{array}{l}\text { 63. I am aware that armyworm thresholds are } \\
\text { available. }\end{array}$ & DS & D & SD & SA & A & AS \\
\hline 64. I use thresholds for armyworms in corn. & DS & $\mathbf{D}$ & SD & SA & A & AS \\
\hline 65. Armyworm thresholds are easy to use. & DS & $\mathbf{D}$ & SD & SA & $\mathbf{A}$ & AS \\
\hline 66. I have time to scout for armyworms. & DS & D & SD & SA & $\mathbf{A}$ & AS \\
\hline 67. I apply insecticides for armyworm control. & DS & D & SD & SA & A & AS \\
\hline $\begin{array}{l}\text { 68. I need more information on armyworm } \\
\text { management. }\end{array}$ & DS & D & SD & SA & A & AS \\
\hline \multicolumn{7}{|l|}{ Wireworms } \\
\hline 69. I can identify wireworms. & DS & D & SD & SA & A & AS \\
\hline $\begin{array}{l}\text { 70. I have heard of monitoring wireworms } \\
\text { using bait stations. }\end{array}$ & DS & D & SD & SA & A & AS \\
\hline $\begin{array}{l}\text { 71. I use bait stations to monitor wireworms in } \\
\text { corn. }\end{array}$ & DS & D & SD & SA & A & AS \\
\hline 72. Wireworm thresholds are too complicated. & DS & $\mathbf{D}$ & SD & SA & $\mathbf{A}$ & AS \\
\hline $\begin{array}{l}\text { 73. I apply seed treatments for wireworm } \\
\text { control. }\end{array}$ & DS & D & SD & SA & A & AS \\
\hline $\begin{array}{l}\text { 74. I apply in-furrow insecticides to control } \\
\text { wireworms. }\end{array}$ & DS & D & SD & SA & A & AS \\
\hline $\begin{array}{l}\text { 75. I need more information on wireworm } \\
\text { management. }\end{array}$ & DS & D & SD & SA & A & AS \\
\hline \multicolumn{7}{|l|}{ White Grubs } \\
\hline 76. I can identify white grubs. & DS & $\mathbf{D}$ & SD & SA & A & AS \\
\hline $\begin{array}{l}\text { 77. I have heard of monitoring white grubs } \\
\text { using baited wire traps. }\end{array}$ & DS & D & SD & SA & A & AS \\
\hline
\end{tabular}




\begin{tabular}{|c|c|c|c|c|c|c|}
\hline Statement & 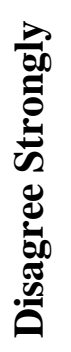 & 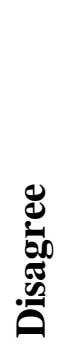 & 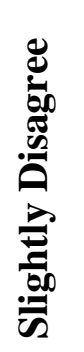 & 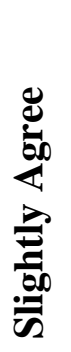 & 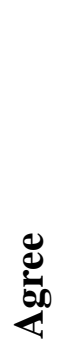 & 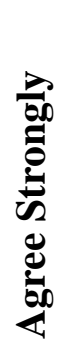 \\
\hline $\begin{array}{l}\text { 78. I use bait stations to monitor white grubs in } \\
\text { corn. }\end{array}$ & DS & $\mathbf{D}$ & SD & SA & A & AS \\
\hline 79. White grub thresholds are too complicated. & DS & $\mathbf{D}$ & SD & SA & A & AS \\
\hline $\begin{array}{l}\text { 80. I have heard about thresholds based on using a } \\
\text { shovel to dig and count white grubs prior to } \\
\text { planting corn. }\end{array}$ & DS & $\mathbf{D}$ & SD & SA & A & AS \\
\hline $\begin{array}{l}\text { 81. I dig and count white grubs before planting } \\
\text { corn. }\end{array}$ & DS & D & SD & SA & A & AS \\
\hline $\begin{array}{l}\text { 82. I check for corn seed pests when I check my } \\
\text { planting depth. }\end{array}$ & DS & D & SD & SA & A & AS \\
\hline 83. I apply seed treatments to control white grubs. & DS & $\mathbf{D}$ & SD & SA & A & AS \\
\hline $\begin{array}{l}\text { 84. I apply in-furrow insecticides to control white } \\
\text { grubs. }\end{array}$ & DS & $\mathbf{D}$ & SD & SA & A & AS \\
\hline $\begin{array}{l}\text { 85. I need more information on white grub } \\
\text { management. }\end{array}$ & DS & D & SD & SA & A & AS \\
\hline
\end{tabular}




\section{Part V: IPM Check List}

Instructions: Please indicate your opinion by putting check marks in the box that best correspond to your response: YES or NO.

\begin{tabular}{|c|c|c|c|}
\hline$\dot{\dot{Z}}$ & Statement & Yes & No \\
\hline 1 & $\begin{array}{l}\text { Do you follow crop rotation to reduce pest populations in your corn } \\
\text { field? }\end{array}$ & & \\
\hline 2 & $\begin{array}{l}\text { Do you scout your corn field to familiarize yourself with the } \\
\text { economic threshold of pests before taking a decision to spray } \\
\text { chemicals? }\end{array}$ & & \\
\hline 3 & Do you estimate weed infestation using weed rating scale? & & \\
\hline 4 & Do you use cultural practices (timely cultivations) to control weeds? & & \\
\hline 5 & Do you rotate your herbicide for weed control? & & \\
\hline 6 & Do you control weeds by spot application of herbicides? & & \\
\hline 7 & Do you use Bt-Corn control European corn borer/rootworms? & & \\
\hline 8 & $\begin{array}{l}\text { Do you calculate the pest defender ratio before taking up an } \\
\text { insecticidal spray? }\end{array}$ & & \\
\hline 9 & $\begin{array}{l}\text { Do you understand the toxicity levels of pesticides (danger, warning, } \\
\text { and caution) by reading the information on the label? }\end{array}$ & & \\
\hline 10 & $\begin{array}{l}\text { Do you use disease-resistant hybrid corn varieties to control } \\
\text { diseases? }\end{array}$ & & \\
\hline 11 & Do you follow clean plow-down to control diseases in corn? & & \\
\hline 12 & $\begin{array}{l}\text { Do you apply balanced fertilization to check development of } \\
\text { diseases in corn? }\end{array}$ & & \\
\hline
\end{tabular}




\section{Part VI: Demographic Information}

1. Please indicate the number of acres of corn you grew in 2008

a. below 50 acres
b. 50 - 100 acres
c. $100-150$ acres
d. 150 - 200 acres
e. 200 - 250 acres
f. above 250 acres

2. Please place a check mark in the box next to the West Virginia County in which you produced corn in 2008 (check all that apply).

a. Jefferson
b. Hardy
c. Mason
d. Berkeley
e. Preston

3. What is your gender?
a. Male
b. Female

4. What is your age?
a. below 20 years
b. $21-30$ years
c. 31 - 40 years
d. $41-50$ years
e. above 50 years 
5. What is your highest level of education?

_ a. Less than high school graduate

b. High school graduate

c. Some college

d. Two - year college degree (AA)

e. Four - year college degree (BA or BS)

f. Graduate degree (Master’s or $\mathrm{PhD}$ )

6. Did you take agricultural classes in high school?

a. Yes

b. No

7. Have you attended IPM training(s)?

a. Yes

b. No 


\section{Comments:}

Thank you for taking the time to complete this questionnaire!

If you have any questions regarding the questionnaire, please contact me or my advisor at:

Hari Vommi: hvommi@mix.wvu.edu

Dr. Stacy A. Gartin: sgartin@wvu.edu

(304) 293-4832 Ext. 4484 
APPENDIX C

Cover Letter 


\section{Dear West Virginia Corn Producer:}

United States of America has a powerful Agricultural sector that not only feeds its own country but also exports tons of agriculture products every day. A substantial part of United States gross domestic production is contributed by agricultural farming. This success cannot be achieved without the dedication, hard work, and perseverance of each and every farmer in the country. I congratulate you for being a part of this great achievement.

I am Hari Vommi, a graduate student at in Agriculture and Extension Education at West Virginia University and conducting a research under the guidance and supervision of my advisor, Dr. Stacy Gartin. We need your help! We seek your cooperation in a thesis study designed to determine the integrated pest management practices adopted by the corn producers and the educational needs of the corn growers in West Virginia. The results of the study will be used to prepare a thesis to partially fulfill the requirements for a Master of Science Degree in Agricultural and Extension Education.

Enclosed is a survey from the Agricultural and Extension Education Department at West Virginia University, which will require about 10 minutes of your time to complete. Your participation is completely voluntary and all the information you provide will be kept as confidential as possible. Please feel free to stop answering the questionnaire at any point of time or to skip any question you do not feel comfortable answering. However, your completion of the survey is crucial to the success of this study. When all the surveys have been returned, information you provide will be combined with that of other producers throughout the state.

You will notice a code number at the bottom left hand corner of your return envelope. This number is only used to keep track of the non-respondents and will be destroyed before that data are analyzed making it in no way possible to track your individual response.

Your participation and return of the questionnaire by April 14, 2009 will be greatly appreciated. Please use the self-addressed, stamped envelope provided to return your survey form.

I thank you in advance for your assistance with our research effort. Your participation will help West Virginia’s Cooperative Extension Service to provide the required information to the State's corn producers.

Sincerely,

Hari Vommi

Stacy A. Gartin, Ph.D.

Graduate Student

Professor \& Chair 
APPENDIX D

Follow-up Letter 
April 15, 2008

Dear:

I am Hari Vommi, a graduate student in Agriculture and Extension Education at West Virginia University and my advisor, Dr. Stacy Gartin are conducting an important research study. The study is designed to determine the adoption levels of integrated pest management practices among corn producers in West Virginia and the educational needs of the corn producers in West Virginia. The results from this study will be used to prepare my thesis to partially fulfill the requirements for a Master of Science Degree in Agricultural and Extension Education.

We have sent you our survey from the Agricultural and Extension Education Department at West Virginia University, two weeks ago. Of course, your participation is completely voluntary and any information you provide will remain confidential.

If you have filled the survey and returned to us, thank you very much. If not kindly spare 10 minutes to fill in the survey. Your participation is crucial to the success of this study.

A self-addressed, stamped envelope is provided to assist with the return of your survey. Your participation and return of the questionnaire by April 27, 2009, will be greatly appreciated. We thank you in advance for your assistance. Your participation will help the West Virginia Cooperative Extension Service as they continue to provide valuable and useful information to West Virginia’s corn producers.

Sincerely,

Hari Vommi

Graduate Student
Stacy A. Gartin

Professor \& Chair 
APPENDIX E

Follow-up Post Card 
April 28, 2009

You recently received a questionnaire as part of my thesis study to determine the adoption levels of integrated pest management practices among corn producers in West Virginia and the educational needs of the corn producers in West Virginia. I realize this is a busy time of year but it will only take a few minutes of your time to answer the survey. Your contribution is vital to the success of this study and the corn producers in our state. Your participation will help the West Virginia Cooperative Extension Service as they continue to provide valuable and useful information to West Virginia's corn producers.

Thank you for your time!

\author{
Hari Vommi \\ Agricultural and Extension Education \\ Davis College of Agriculture, Forestry, and Consumer Sciences \\ West Virginia University \\ 2056 Agricultural Sciences Building \\ P.O. Box 6018 \\ Morgantown, WV 26505-6108
}


APPENDIX F

Cover Letter for Second Mailing 
May 10, 2009

Inside address

Dear:

A few weeks ago you received a survey concerning the adoption levels of integrated pest management practices among corn producers in West Virginia and the educational needs of the corn producers in West Virginia. As of today, we have not received your response. In the event the original materials were lost, we have included a second copy of the questionnaire. Please take a few minutes out of your busy schedule and complete the questionnaire. Your response is vital to success of this research effort.

The results of this research will assist the Extension Service in providing the necessary educational and practical training associated with the implementation of IPM. This information will be valuable to all the corn producers in West Virginia. You are only one of 100 chosen to participate in the important study.

(Mr. Last Name), enclosed is our survey from the Agricultural and Extension Education Department at West Virginia University, which will require about 10 minutes of your time to complete. Of course, your participation is completely voluntary and any information you provide will remain confidential. Your participation is crucial to the success of this study.

A self-addressed, stamped envelope is provided to assist with the return of your survey. Your participation and return of the questionnaire by April 30, 2009, will be greatly appreciated. We thank you in advance for your assistance. Your participation will help the West Virginia Cooperative Extension Service as they continue to provide valuable and useful information to West Virginia's corn producers. We thank you in advance for your assistance and cooperation. We sincerely appreciate your time and effort as corn season awaits us.

Sincerely,

Hari Vommi

Graduate Student
Stacy A. Gartin

Professor \& Chair 
VITA

September 3, 1972 Born: Visakhapatnam, Andhra Pradesh, India.

March 1988 Passed standard X: St Aloysius High School, Visakhapatnam.

March 1990 Passed standard XII: Mrs. A.V.N. College, Visakhapatnam.

December 1995 Bachelor of Science in Agricultural Sciences, Andhra Pradesh

Agricultural University.

1996 to 1997

Worked in a Micro-Irrigation Company.

1998 to 2002

Worked in a Multi-National Agrochemicals Company in various capacities.

2003 to 2008

Worked as an Agricultural Officer (Extension Agent) in State

Department of Agriculture, Government of Andhra Pradesh.

2008 to 2009

Master of Science in Agricultural and Extension Education, West

Virginia University.

John

$\mathrm{H}$. 